Tectonophysics

December 2016, Volume 693, Part A, Pages 96-115

http://dx.doi.org/10.1016/j.tecto.2016.05.038

http://archimer.ifremer.fr/doc/00343/45372/

(C) 2016 Elsevier B.V. All rights reserved.

\title{
Transform continental margins - Part 2: A worldwide review
}

\author{
Mercier De Lepinay Marion ${ }^{1,5}$, Loncke Lies ${ }^{1,{ }^{*}}$, Basile Christophe ${ }^{2,{ }^{*}}$, Roest Walter ${ }^{3}$, Patriat Martin ${ }^{3}$, \\ Maillard Agnès ${ }^{4}$, De Clarens Philippe ${ }^{5}$
}

${ }^{1}$ Univ. Perpignan Via Domitia, CEntre de Formation et de Recherche sur les Environnements Méditerranéens, UMR 5110, 52, avenue Paul Alduy, F-66860, Perpignan, France.

${ }^{2}$ ISTerre, UMR-CNRS 5275, Observatoire des Sciences de l'Univers de Grenoble, Université Joseph

Fourier, Maison des Géosciences, 1381 rue de la Piscine, 38400 St. Martin d'Hères, France

${ }^{3}$ Ifremer, Centre de Brest, Institut Carnot - Ifremer EDROME, UR Géosciences Marines, CS 10070,

29280 Plouzané, France

${ }^{4}$ GET-OMP-Université Paul Sabatier, 14, av. E. Belin, 31400 Toulouse, France.

${ }^{5}$ TOTAL SA - 2 place Jean Millier, 92078 Paris La Défense, Cedex, France

* Corresponding authors : Lies Loncke, email address : lies.loncke@univ-perp.fr ;

Christophe Basile, email address : christophe.basile@ujf-grenoble.fr

\begin{abstract}
:
We present a global inventory of transform continental margins, based on both a worldwide comparison of continent-ocean boundary identifications with oceanic fracture zones traces, and a compilation of published regional studies. This inventory increases the number of identified transform margins from 29 to 78 . These margins represent $16 \%$ of continental margins in cumulative length and $31 \%$ of nonconvergent margins. We include morphological data, published upper crustal sections, continent to ocean transition locations and published Moho shape data in the new database. This review confirms that continent to ocean transitions are sharper at transform margins than at divergent margins. It also emphasizes the structural diversity of transform margins. Associated with one third of transform margins, we define marginal plateaus as a new type of relief that corresponds to a flat but deep surface inside the continental slope, and that may be inherited from crustal thinning prior to transform faulting. Transform margin initiation appears to be favoured along propagating oceans and within cold and thick lithospheres.
\end{abstract}

\section{Highlights}

- Our global inventory identifies 78 transform continental margins - Transform margins represent $31 \%$ of non-convergent margins in cumulative length. Many transform margins have a marginal plateau of intermediate depth Transform margins display an important variety in shape and structure Marginal plateaus are often found between two oceans and in thinned continental crust domains

Keywords : Transform margin, continental margin physiography, marginal ridge, marginal plateau 


\section{Introduction}

Since Mascle (1976) distinguished transform from rifted divergent continental margins, transform margins were relatively poorly studied in comparison with the latter. Although their understanding has many academic and industrial implications, these margins are difficult to investigate by reflection seismic methods because of the steepness of the structures and their non-cylindrical nature, in particular near their intersection with rifted divergent margins. Furthermore, transform margins did not represent a significant target for oil industry before the discovery of the Jubilee field offshore Ghana in 2007.

We aim to review continental transform margins globally and to present a new catalogue that allows comparing all available morphological and structural data along those margins and discussing their common attributes, diversity and conditions of initiation. Our study follows up on a previous publication entitled "Transform continental margins -part 1: concepts and models" (Basile, 2015) in which theoretical models of transform margins formation were presented. 
The first transform margins that were identified are located at the landward prolongation of the large Equatorial Atlantic oceanic fracture zones. They result from two stages of strike-slip motion along a transform fault, first within continental lithosphere, then between continental and oceanic lithospheres, finally followed by a passive stage after the passage of the oceanic accretion axis along the transform margin (see Figure 1 ; Scrutton 1979; Mascle and Blarez, 1987; Basile 2015). Each end of a transform margin is connected with a divergent margin segment. The inner corner of the transform margin is defined as the connection with a concave shape towards the ocean in map view, and the outer corner as the connection with a convex shape towards the ocean (Basile, 2015 and Figure 1). Oceanic crustal accretion started in the inner corner of the transform margin, and subsequent seafloor spreading resulted in the sliding of the spreading axis towards the outer corner (Figure 1 and Basile, 2015). 
Transform margins are characterized by sharp continent to ocean transitions (Sage et al., 2000) and exhibit specific bathymetric features, including steep slopes and marginal ridges (e.g Francheteau and Le Pichon, 1972; Mascle, 1976). Marginal ridges correspond to basement highs that parallel the continent to ocean boundary along several transform margins. In some cases, they are visible in bathymetry (Arens et al., 1971, Basile et al., 1993). Although their presence seems to be typical of transform margins, their origin is still a matter of debate: related to wrench tectonics, thermal or flexural processes (see Basile, 2015, for complete review).

Some margins, such as the Agulhas (e.g. Ben-Avraham et al., 1997; Parsiegla et al., 2009), Côte d'Ivoire-Ghana (e.g. Basile et al., 1998) and Exmouth (e.g. Lorenzo and Vera, 1992) margins have been the object of case studies, but global synthesis studies are still missing.

Earlier transform margin compilations by Scrutton (1982), Lorenzo (1997) and Bird (2001) compared the crustal structure of transform margins and their evolution to the conceptual models of evolution proposed by Scrutton (1979), Mascle and Blarez (1987) or Lorenzo and Vera (1992). But these catalogues differ from each another, and did not aim to be exhaustive as they did not use global data sets nor did they use homogeneous methods for the identification of transform margins. As a corollary, no complete database is available to compare transform margins to each other, for example in terms of age, length, geodynamic setting or structure.

Many questions would, however, benefit from such a database: are all transform margins displaying common attributes like marginal ridges or sharp ocean to continent transitions? Are they steeper than rifted margins? Do they share common physiographic 
attributes related to their specific structure? What can we learn about initiation conditions by comparing those margins in length, age, geodynamic setting, or structure? In order to answer these questions, we established a list of transform margins identified using a simple definition and available global geophysical data sets. We then used this database to gather physiographic, crustal and upper crustal information on transform margins. This allowed to identify some structural and sedimentary characteristics, then to discuss the factors and processes that favour the initiation of transform margins, and that induce variability along them and between them, including their vertical movements. 


\section{Methods for identification of transform margins}

Following Basile (2015), we define transform margins as continent-ocean boundaries superposed to active, or previously active transform faults. We used this definition as a guideline to identify transform margins.

As they usually represent the continent-ward prolongation of oceanic fracture zones, we identified the transform margins by combining worldwide compilations of the continent-ocean boundary and of oceanic fracture zones (Figure 2). We expect this simple criterion to provide a catalogue as robust and comprehensive as possible. Where possible, we complemented these results using regional plate kinematics studies describing the first stages of oceanic opening.

\subsection{1. Fracture zones}

We used the oceanic fracture zones compilation published by Matthews et al. (2011), where fracture zones were automatically detected from a vertical gravity gradient 1 minute of arc (1.8 km) grid derived from satellite data (Sandwell and Smith, 2009). This is probably the most complete compilation, but it was dedicated to the structure of the oceanic lithosphere. Therefore, not all fracture zones were mapped all the way to the continental margin. In places, we extended the fracture zones continent-ward following bathymetric reliefs, but close to the continental margins, the thickening of the sedimentary cover often masks the structure of the oceanic crust. In such cases, we extrapolated fracture zones from the age offsets of the oceanic floor as mapped by Müller et al. (2008) from interpolation of marine magnetic anomalies. 


\subsection{2. Continent-ocean boundary}

The continent-ocean boundary is a concept whose definition and precise mapping are still in debate. Instead of a sharp boundary, most continental margin studies refer to a transition zone, which may be several tens, sometimes hundreds of kilometres wide (e.g. Geoffroy, 2005; Minshull, 2009). There is no published academic map of the continentocean boundary or transition zone for the entire world. We used either a map proposed by Exxon (1985), based on regional compilations of continental margins studies, or the edge of the oceanic crust as mapped by Müller et al. (2008). In this case we extrapolated the continent-ocean boundary from the location of the oldest oceanic magnetic anomaly, using the estimated age of breakup and seafloor spreading rate.

In most cases we used the map from Exxon (1985), but where it presents a better resolution, we preferred the map by Müller et al. (2008), for example where it allows to distinguish several margin segments with changing strikes instead of a smooth and linear margin (e.g. the Mozambique margin). 


\subsection{Plate kinematics}

To complete and improve this approach we compared and, if needed, corrected the catalogue derived from the fracture zone and continent-ocean boundary trends with regional plate kinematic reconstructions for individual oceanic domains. This is especially important for small and young oceanic basins, such as the Gulf of California, Cayman Trough or back-arc basins, for which global maps lack resolution. This is also the case where the plate kinematics changed after continental breakup, implying that the strike of the recent fracture zone does not reflect syn-rift kinematics direction. For example, the Svalbard margin is not directly in line with an oceanic fracture zone. However it is interpreted as a transform margin because it experienced a first phase of transform movement after which a plate kinematic reorganisation caused the oblique opening of the Fram Strait (Breivik et al., 2003).

\subsection{Limits of the method}

It is important to note some limitations and uncertainties inherent to the methodology we used:

- Regional compilations of the continent-ocean boundary and fracture zones sometimes have insufficient resolution for transform margin identification. They do not allow accurate interpretation for some margins, especially where post-breakup sedimentation or volcanism is important or where magnetic anomalies are absent or poorly identified (e.g. the upper Cretaceous quiet magnetic zone for the Equatorial Atlantic margins).

- Continent-ocean boundaries and oceanic fracture zones are often not mapped in backarc basins. Therefore, we have likely under-estimated the number of transform margins in these basins. For example, the Andaman back-arc basin opens in a very oblique 
setting and could include long transform margins, but the continent-ocean boundary is not clearly defined (Curray, 1995).

- Our definition of transform margins is related to the obliquity of the continent-ocean boundary as compared to the trend of oceanic fracture zones and transform faults. Theoretically, this obliquity should be equal to zero to define a transform margin segment. For non-zero obliquities, margins should then be considered as oblique (Turner et al., 2003, Basile, 2015). Based on the resolution of the available datasets, we estimated that it was reasonable to consider a tolerance of $15^{\circ}$ between the trends of oceanic fracture zone and of the continent-ocean boundary to define a transform margin. This value of this threshold angle is, of course, debatable. Increasing the tolerance value implies that some oblique margins may be integrated in the transform margin inventory, while decreasing it would result in the omission of some transform margins.

- Most often, we identified conjugate margins when they were lined up with the same oceanic fracture zone. For example, the conjugate Agulhas and Falkland/Malvinas margins are aligned with Agulhas-Falkland/Malvinas Fracture Zones (Ben-Avraham, 1993). Young oceanic accretion axis, such as that in the Gulf of Aden and the southern part of the Gulf of California allow for an easy correlation of conjugate transform margins. In some older basins, such as the Davis Strait at the junction between the Labrador Sea and Baffin Bay, the transform margins are still connected, allowing identifying them as conjugate margins. However, in other older basins, several transform margins lack a conjugate margin for several reasons:

* The conjugate margins of the western Australian transform margins (Perth margin, Exmouth plateau margins) were part of "Greater India" and were involved in the 
Himalayan belt development during India Asian collision (Veevers and McElhinny, 1976).

* Kinematic rearrangements during or shortly after continental breakup, as is the case at North East Greenland, eastern Greenland ridge, Svalbard and Senja transform margins (Engen et al., 2008), may have disrupted the direct alignment between conjugate transform margins and oceanic fracture zones.

* Limited resolution of the ocean-continent boundary map may prevent identification of short conjugate transform margins. For example, the five short transform margins that we identified on the North American side of the Central Atlantic, have no conjugate on the African side (Figure 3)." 


\section{Results}

\subsection{A worldwide database}

Our approach resulted in the identification of 78 transform margins (Table 1, Figure 3). 28 transform margins were identified using the compilation of oceanic fracture zones of Matthews et al. (2011), 7 other margins were derived from fracture zones mapped by Müller et al. (2008). From the comparison with regional studies and kinematic data, we added 43 transform margins to the data set (labelled $\mathrm{K}$ in Table 1 ). Only $30 \%$ of the transform margins we identified were previously listed in the literature (Scrutton, 1982; Lorenzo, 1997; Bird, 2001). Inversely some bathymetric structures that were previously defined as transform margins are not included in our inventory because they do not meet our criteria. Examples include the Owen oceanic fracture zone, which is not a continental margin because it is not situated at the continent-ocean boundary, and the Queen Charlotte continental margin, which is associated with convergence between tectonic plates. 
With an aggregated length of $25500 \mathrm{~km}$, transform margins represents $16 \%$ of the length of continental margins, and $31 \%$ of that of non-convergent continental margins. In our database, transform continental margins are not observed around the Pacific Ocean, where convergent margins prevail (Figure 3). Besides those occurring in the main oceans, transform margins exist in back-arc basins, either active (e.g. Woodlark back-arc basin) or inactive (North of New Zealand). Most of the transform margins are, however, located in the Atlantic and Indian oceans (Figure 3). They are not regularly spaced. Some areas have numerous transform margins, such as the Equatorial Atlantic Ocean, the Labrador Sea, the Norwegian-Greenland Sea, and the margins of South East Africa and Western Australia. Other domains are almost devoid of transform margins, such as the South and Central Atlantic Oceans.

\subsection{Geodynamic settings and evolution stages}

$25 \%$ of the identified transform margins are located between two initially unconnected ocean basins of different ages: during the early stages of their formation they were at the tips of a propagating ocean. This is the case for the northern Demerara and southern Guinea plateaus between the Central Atlantic and the Equatorial Atlantic Oceans; the western and eastern Tasman transform margins between the Tasman Sea and the Antarctic Ocean; the Agulhas and Falklands/Malvinas transform margins between the Antarctic and South Atlantic Oceans; and the NorthEast Greenland and Svalbard transform margins between the North Atlantic and Arctic Oceans (Figures 4 and 5).

On the contrary, $58 \%$ of the identified transform margins are located inside oceanic domains of homogeneous age. 38\% are located in oceanic domains derived from the 
Pangea breakup (Figures 4 and 5): half of them in the Atlantic Ocean and the other half in the Indian Ocean. With respect to their tectonically active stage, the oldest identified transform margins are Jurassic in age and located in the Somali and Mozambique basins, the Southwest Indian Ocean, the Central Atlantic Ocean and the Gulf of Mexico (Pindell and Keanan, 2001). Many other transform margins are associated with the Cretaceous continental breakups in the South, Equatorial, and North Atlantic Oceans,including the Labrador Sea, and the Southeast Indian Ocean.

Finally, $17 \%$ of transform margins occur in small oceanic domains such as the Labrador Sea and Baffin Bay, or in back-arc basins such as the Scotia Sea, Woodlark basin, Cayman Trough or the Gulf of California, which are mainly Cenozoic in age.

The length of transform margins also provides information on their geodynamic evolution. For a given seafloor spreading rate, longer transform experienced longer periods of intracontinental and continent-ocean activity (Basile, 2015). The length of the identified transform margins is highly variable, ranging from 30 to $1310 \mathrm{~km}$ (Woodlark and Falkland transform margins, respectively, Table 1). $74 \%$ of the transform margins fall within the length-range of 45-400 km (median $265 \mathrm{~km}$ : Figure 6A). The mean length is $320 \mathrm{~km}$, but this mean value is biased by the presence of 11 transform margins that are longer than $500 \mathrm{~km}$, the longest being the Falkland/Malvinas and the Agulhas margin (1310 and $990 \mathrm{~km}$, respectively), the Somali basin margin (1140 km), the Cayman Trough transforms (890 km) and the Bahamas transform margin (835 km). The shortest transform margins are located in the Woodlark basin $(30 \mathrm{~km})$, the Central Atlantic Ocean (45 km) and the Gulf of Aden (50 km).

Since transform margin evolution is diachronous along the strike of the transform fault, the age of the oceanic crust decreases from the inner corner to the outer corner along a 
single transform margin (Basile, 2015). The older ages correspond to the beginning of transform margin formation and the youngest ages indicate the end of transform activity along the same margin. We estimated the duration of the active transform stage from the difference in age of the oceanic crust (from Müller et al. (2008), Figure 4) at the outer and inner corners. This duration (and hence the length of a margin) may have an impact on the intensity of deformation. The average duration of the active stage is 12 Myr, but most are shorter than $10 \mathrm{Ma}$, with few others between 15 and 25 Myr (Figure 6B). The maximum duration is 50 Myr for the Falklands-Malvinas, which is the longest transform margin of our database.

Today, most transform margins are in the passive stage of their evolution. The Gulf of California and Cayman Trough are the only areas where transform margins are active, with ocean accretion taking place at the foot of the transform margin. However, in some areas, seafloor spreading stopped before the transform margin completed all its evolutionary stages. This is the case for the Somali basin, where ocean accretion stopped 110 Ma ago, the Davis Strait transform margin since spreading stopped in the Labrador Sea, and the southern Exmouth transform margin.

\subsection{3 Morphology}

We extracted bathymetric cross-sections across all identified transform margins from the ETOPO1 dataset (Amante and Eakins, 2009). To facilitate handling and comparison of the continental slope domain, cross-section are all $400 \mathrm{~km}$ long at $100 \mathrm{~km}$ spacing. They are perpendicular to, and centred at, the continent-ocean boundary as defined by Exxon (1985) and Müller et al. (2008). We did not include the margins where the bathymetry is obviously controlled by some processes that are not directly related to 
transform margin evolution, such as post-transform volcanism, large-scale gravitydriven collapses or the onset of large sedimentary fans. Finally, 80 profiles remained (Figure 7), illustrating the morphology of 22 different margins, listed in Table 1.

On the selected cross-sections, the continent-ocean boundary is always situated below the continental slope (Figure 7a). We also centred all cross-sections on the slope-break allowing a better identification of the physiographic domains (Figure 7b.).

For each cross-section, we computed the mean slope values. Local features, such as canyons, can increase the slope value. Hence, the use of a mean slope value is dependent on the resolution of the bathymetry data. To reduce these local effects, we first defined the physiographic domains on each section. Subsequently, the regional slope was estimated for each domain using a linear regression.

Four main physiographic domains can be identified in transform continental margins (Figures 7 and 8):

1) The continental platform (or shelf) is located between the coast (sea level) and the shelf-break, which separates it from the slope. Only 54 cross-sections, taken across 19 transform margins reach the continental platform. Many of the profiles do not reach the shoreline, mainly because they end along the strike of a divergent margin adjacent and perpendicular to the transform margin. Where observed, the depth of the shelf-break separating the platform from the slope ranges from 40 to $240 \mathrm{~m}$. This is very similar to what can be observed worldwide on all continental margins. The average slope of continental platforms is $0.1^{\circ}$ in an ocean-ward direction (Table 2).

2) The continental slope offshore of the shelf-break, defined by slope values higher than $1^{\circ}$ (Porter-Smith et al., 2012). In transform margin cross-sections, the continental slope has an average slope of $4.2^{\circ}$ (Table 2, Figure 9), which is slightly steeper than the 
average slopes $\left(3^{\circ}\right)$ of divergent margins (Rouby et al., 2013). 14\% of transform margins display a slope steeper than $9^{\circ}$, with a maximum of $14^{\circ}$ observed for a part of the Falklands margin. Local slopes reach $20^{\circ}$, although those values highly depend on the resolution chosen (Figure 9). The width of the continental slope ranges from $16 \mathrm{~km}$ for the steepest margins $\left(14^{\circ}\right.$, Falkland-Malvinas margin) to $165 \mathrm{~km}$ (Newfoundland margin, close to the inner corner).

3) For a third of the transform margins (Table 1), a deep, planar and sub-horizontal plateau is located between the platform and the lower continental slope. It separates the upper and lower slope of the margin (Figure 8A). We called this type of domain "marginal plateau".

In our compilation, we identified marginal plateaus along 21 transform margins. The selected bathymetric cross-sections cut 14 of those marginal plateaus. Their widths vary from 9 to $124 \mathrm{~km}$ (Table 2), but the width of some of the largest marginal plateaus such as the Falklands $(290 * 900 \mathrm{~km})$ are underestimated as we were using $400 \mathrm{~km}$ long crosssections. The depth of the marginal plateaus ranges from $100 \mathrm{~m}$ to $3400 \mathrm{~m}$, with an average of $1250 \mathrm{~m}$.

Most plateaus occur along the entire length of their transform margin (Figures 10 and 11). 18 marginal plateaus are located at the intersection of oceanic domains with different break-up ages and/or opening directions (Figure 5), and only 3 are located in oceanic domain with homogeneous break-up ages, at the outer corner of transform margins (Côte d'Ivoire-Ghana: Figure 12, Agulhas, Perth: Figure 10d). They have either rectangular (Demerara, Exmouth plateaus) or triangular shapes (Guinea, Vöring plateaus) (Figure 10), but are always bounded by a transform margin along one side and by older transform or divergent margins along the other sides. 
4) The rise is deeper and generally less steep than the continental slope. It is a domain with variable slopes, which are most often less than $1^{\circ}$ (Rouby et al., 2013). The rise forms the transition between the continental slope and the abyssal plain, which is essentially horizontal.

Finally, Along-strike variations of morphologies are observed at $70 \%$ of the investigated margins between their inner and outer corners. In most all these cases, the slope-break is more elevated towards the inner corner than that towards the outer one. The Côte d'Ivoire-Ghana margin is probably the most illustrative case (Figure 12). However, there is no rule and some transform margins are characterized by similar depths in the inner and outer corners, and a deeper middle part of the transform margin. This is the case for the marginal plateau of the Falkland-Malvinas margin (Figure 11). This situation is likely due to some differences in crustal thicknesses (see discussion in section 4.6).

\subsection{4. Upper crustal structures}

Seismic studies were published only for half of the transform margins listed in Table 1. From this literature, we compiled eleven representative line drawings of seismic sections perpendicular to six transform margins (Figure 13). We use these seismic lines to investigate and compare the upper crustal structure of transform margins. We use published results, when available, to comment about the origin of the observed structures.

All sections present a regional erosional unconformity between a lower unit, which is deformed along the transform margin, and an upper sedimentary unit, which isdeformed. To be cautious we name this unconformity the post-deformation unconformity, to distinguish it from the post-transform unconformity, which was 
theoretically defined by Basile 2015 (see discussion in section 4.2). According to the kinematic models of evolution of transform margins, the post-transform unconformity is diachronous along the margin and post-dates the post-rift unconformity (Mascle and Blarez, 1987; Basile et al., 1993, Basile, 2015).

In the following description, we indicate by "marginal ridge" the basement ridges that are observed along transform margins, near the top of the continental slope. These ridges can be visible in the bathymetry or buried by sediments.

\section{Falklands-Malvinas (Figures $13 A$ and B)}

Both sections through the Falklands-Malvinas margin cross a marginal plateau (Figure 11). A regional unconformity separates a lower deformed unit from an upper unit that is un-deformed. This unconformity locally reaches the basement. Towards the inner corner of the transform margin (Figure 13A), this post deformation unconformity and the overlying sediments are tilted towards the continent, defining a $160 \mathrm{~km}$-wide marginal ridge. The upper sediments are also eroded by a later unconformity (in green, Figure 13A). This tilt increases when approaching the oceanic crust, suggesting an upward flexure of the continental edge. On the contrary, towards the outer corner of the margin, the unconformity is tilted ocean-ward (Figure 13B).

In both cases, there is either no, or very restricted, recent sediment deposition along the continental slope, with basement (granites and gneiss: Lorenzo and Wessel, 1997) outcropping at the continental slope in the inner corner of the margin and eroded sediments found at the location of the continental slope at the outer corner. The erosion of the continental slope is probably related to its steepness (inner corner), and to deepsea currents that transit along the Falkland-Malvinas Escarpment (outer corner) (Hernandez-Molina et al., 2010). Along the inner corner, the main post-deformation 19 
depocenter is observed landward of the marginal ridge, and the uplifted continental edge seems to have formed a dam preventing seaward sediment transport. Towards the outer corner, the thickest pile of sediment accumulates near the continent-ocean boundary (Figure 13B).

\section{Agulhas (Figures 13C and D)}

The Agulhas margin is conjugate to the Falkland-Malvinas margin, but its cross-sections display quite different structures. The two sections shown in Figure 12 are located in the central part of this transform margin (Figure 11), across a marginal plateau, the edge of which is called the Diaz marginal ridge (Ben-Avraham et al., 1993, 1997).

Post-deformation sediments onlap onto the marginal ridge, that is not entirely buried by sediments and is visible in the bathymetry. The nature of this ridge is unknown. It can be composed either of Precambrian or Paleozoic granites and metamorphic basement, or of highly deformed Mesozoic sediments (Ben-Avraham et al., 1993). The erosional unconformity that truncates the acoustic basement is cut by normal faults. Ben-Avraham et al., 1003 reported the existence of a ridge similar to the Diaz marginal ridge on the outermost part of the transform margin, The two ridges are situated in an en echelon position, suggesting they belong to the same strike-slip structure.

The marginal plateau includes the southern edge of the Outeniqua Basin, where more than $9 \mathrm{~km}$ of sediments are deposited. Where the marginal ridge is elevated (central/outer corner section), it acted as a dam for the Outeniqua Basin sediments that onlap this relief. Where the marginal ridge is less developed (central/inner corner section), numerous gravity-driven slides, including a very large slide identified by Dingle $(1977 ; 750 \times 106 \mathrm{~km})$, affect the post-transform sediments. As is the case for the inner Falklands-Malvinas plateau, the basement outcrops along the continental slope, 20 
indicating either a lack of sedimentation or erosional processes probably driven by deep-water currents along the margin (Uenzelmahn-Neben and Huhn, 2009).

\section{Côte d'Ivoire-Ghana (CIG) (Figures 13E, F and G)}

The section located at the outer corner (Figure 12 and Figure 13G) of the Côte d'IvoireGhana margin crosses a small marginal plateau. The edge of the plateau follows a $2 \mathrm{~km}$ high marginal ridge, which is buried by sediments on one side, and represents the continental slope on the other side. Pre-, syn- and post-rift strata are more than $5 \mathrm{~km}$ thick below the marginal plateau (Guiraud et al. 1997, Basile et al., 1998, Mascle et al., 1998). The marginal ridge consists of at least 3 kilometres-thick deformed sediments, that outcrop along the continental slope, and are capped towards the continent by a post-deformation unconformity (Basile et al., 1998). This unconformity is tilted towards the continent. The concave shape suggests a flexural mechanism for the uplift (Basile and Allemand, 2002). Post-deformation sediments onlap the unconformity with a fanshape geometry, indicating that uplift occurred after the end of deformation (Basile et al., 1998).

Ocean Drilling Program Leg 159 drilled the post-deformation unconformity in several places near the outer corner of the Côte d'Ivoire-Ghana transform margin (Mascle et al., 1995). The first sediments lying on the post-deformation unconformity are Albian in age, but proved to be diachronous, younger towards the continent-ocean transform boundary, and also younger towards the outer corner (Basile et al., 1998). This unconformity is always older than the end of the active stage along the margin that was formed during Santonian times (Basile et al., 1993). This post-deformation unconformity is not coeval with the end of transform motion, and differs from the posttransform unconformity postulated in theoretical models (Basile, 2015). This has been 21 
interpreted as reflecting the migration of the strike-slip deformation zone towards the continent-ocean boundary through time (Basile et al., 1998).

In the central part of the margin (Figure 12 and Figure 13F), the section crosses the continental platform. There, the basement together with pre- and syn-transform sediments are tilted towards the continent, but the post-deformation unconformity is slightly tilted ocean-ward. Both the basement and syn-transform sediments outcrop along the steep continental slope where no recent sedimentation takes place.

The section located at the inner corner (Figure 12) displays very different features (Figure 13E). The pre- and syn-rift sediments are deformed by strike-slip faults with flower structures visible in seismic lines (Antobreh et al., 2009). There, the sedimentary units together with the post-deformation unconformity are tilted seaward. Postdeformation sediments have been deposited on the continental slope. This section is close to the adjacent divergent margin and appears to represent a transition between transform and divergent margins.

\section{Vøring transform margin (Figure 13H)}

We selected a representative section across the Vøring margin marginal plateau (Figure 10c). This section is very similar to the outer corner section of the Côte d'Ivoire-Ghana margin (Figure 13G). They both display a marginal ridge at the edge of the plateau, with a post-deformation unconformity tilted toward the continent, and post-deformation sediments onlapping onto this unconformity. The Vøring margin is a volcanic-type margin and the pre- and syn-transform units consist of sediments, basalt flows and intrusions (Berndt et al., 2001, Raum et al., 2006). The marginal ridge can be followed along the entire transform margin, but it is less elevated towards the outer corner (Berndt et al., 2001). There is no sedimentation on the continental slope. 
Southern Exmouth transform margin (Figure 13K)

This section traverses a marginal plateau (Figure 10d), bounded towards the ocean by a marginal ridge, capped by a post-deformation unconformity that is tilted towards the continent. The marginal ridge is more than $50 \mathrm{~km}$ wide, and is constituted of $10 \mathrm{~km}$ thick deformed Palaeozoic and Mesozoic sediments (Exon et al., 1982; Lorenzo and Vera, 1992, Direen et al., 2008) folded in a wide anticline. Lorenzo and Vera (1992) estimated up to $3.5 \mathrm{~km}$ uplift of the marginal ridge from the amount of eroded sediments along the continental slope. They also reported vertical faults and negative flower structures delimiting rotated blocks. Volcanic intrusions could have occurred close to the oceancontinent boundary (Rey et al., 2008).

\section{Demerara plateau (Figures 13I and J)}

The two sections related to the Demerara plateau cross a marginal plateau (Figure 10a) underlain by more than $8 \mathrm{~km}$ of deformed pre- and syn-transform sediments. An upper Albian angular unconformity indicates erosion of these sediments. As for the Côte d'Ivoire-Ghana post-deformation unconformity, the Demerara unconformity predates the end of strike-slip displacement along the active transform margin (Basile et al., 2013).

The unconformity is tilted towards the continent at the inner corner, defining a $160 \mathrm{~km}$ wide marginal ridge, and seaward near the distal outer corner (Basile et al., 2013; Loncke et al., in press). At the inner corner, post-transform sediments prograde above the unconformity (Figure 13I). Near the outer corner (Figure 12J, giant gravity-driven slides remobilized the post-transform sedimentary cover close to the continent-ocean boundary (Loncke et al., 2009; Pattier et al., 2013: Loncke et al., in press). There is no sedimentation on most of the continental slope. This has been attributed to the 23 
steepness of the slope (Loncke et al., 2009). Deep currents may also regularly erode the slope (Gonthier et al., 2002; Tallobre et al., 2014; Loncke et al., in press).

\subsection{5. Moho shape and ocean to continent transitions}

We also compiled available crustal cross-sections perpendicular to transform margins. Crustal structure was studied for only $13 \%$ of the compiled transform margins by either gravimetry or wide-angle seismics.

Transform margins show a narrow necking zone for the continental crust, typically 50 km-wide, and a steep Moho slope (Figure 14). On the Côte d'Ivoire-Ghana transform margin, wide-angle seismic data combined with gravity models show that the transition between continent and ocean is very sharp at a crustal scale, with a nearly vertical Moho between the continental and oceanic domains (Sage et al., 2000). Offshore French Guiana, the slope of the Moho ranges from $11^{\circ}$ to $18^{\circ}$ across the $50 \mathrm{~km}$-wide necking zone, while it is $\sim 3^{\circ}$ across the adjacent Amazon divergent margin, which has a $200 \mathrm{~km}$ wide necking zone (Figure 15).

Harry et al. (2003) published a compilation of 18 crustal sections of divergent margins, and contrasted them with 6 sections of transform margins. We updated this compilation by adding 5 recently published transform margin sections (Agulhas: Parsiegla et al., [2009]; Senja: Czuba et al., [2011]; Vøring: Raum et al., [2006]; northern Demerara and French Guiana: Greenroyd et al., [2008]) (Figure 15). In this compilation, crustal thickness variations across passive continental margins were computed from the Moho shape at the transition between oceanic and continental crusts for divergent and transform passive margins. 
Oceanward of this transition, along Côte d'Ivoire-Ghana, Newfoundland, North Baffin (Sage et al., 2000 and references therein), French Guiana (Greenroyd et al., 2007) and Demerara plateau (Greenroyd et al., 2008), the oceanic crust emplaced along the margin is anomalously thin, from 3 to $5 \mathrm{~km}$-thick, and oceanic layer 3 may be missing (Newfoundland: Keen et al., 1990; North Baffin Bay: Reid and Jackson, 1997). This may indicate an abnormally cold ocean accretion process, also observed along oceanic transform faults (Sage et al., 2000).

\section{Discussion}

\subsection{Morphological and structural attributes of transform margins}

Using our compilation, we can compare the observed attributes for transform margins with what had been previously defined from case studies as the main characteristics of transform continental margins (e.g. Mascle and Blarez, 1987; Basile et al., 1993). Transform margins were thought to systematically display a narrow and steep continental slope underlain by a very sharp necking zone close to the continent-ocean boundary, and an elevated marginal ridge at the top of the continental slope.

The first and main result of our systematic compilation of transform margins is that these observations, if frequent, are not systematic, and therefore cannot be used as characteristic for transform margins. Transform margins present a previously unexpected variability, both between margins and along-strike within a single margin. Conjugate margins, such as the Falkland-Malvinas and Agulhas margins, commonly do not display similar structures.

For example, among the bathymetric features, the continental slope in transform margins is, on average, steeper than in divergent margins, and often very steep $\left(>10^{\circ}\right)$, 25 
but some transform margins present gentle slopes in the range of divergent margins. The type and age of the outcropping rocks varies with the steepness of the slope: eroded basement and pre- to syn-rift sediments are associated with steep slopes, while recent sediments accumulate on gentle continental slopes.

Similarly, a marginal ridge does not occur along all transform margins. On the contrary, many transform margins segments are tilted and deepening towards the ocean. Marginal ridges were identified in only eleven transform margins imaged by geophysics (Table 1). In many cases, marginal ridges only occur along a limited segment of the margin, at the edge of a marginal plateau, never at the edge of the continental shelf.

Finally, transform margins always display a regional post-deformation unconformity, that cuts deformed sedimentary or basement units, and is overlain by undeformed sediments. In marginal plateaus, this unconformity affects wide areas, and is not restricted to the narrow strip where strike-slip deformation is localized at the continental edge. This unconformity is always sub-horizontal at a regional scale, with the exception of the transform boundaries. It implies a regionally homogeneous subsidence, with additional uplift (along marginal ridges) or ocean-ward tilting along the transform border. Such post-deformation unconformities have been drilled in two places: Demerara and Côte d'Ivoire-Ghana. In both cases they correspond to an erosional surface, which was formed at sea level (Demerara: Gouyet, 1988; Côte d'Ivoire-Ghana: Mascle et al., 1995). We discuss the significance of this unconformity in the next section.

\subsection{Marginal ridges, post-transform unconformity and vertical movements}

Marginal ridges were considered typical features of transform margins (Basile et al., 1993; Basile and Allemand, 2002). They were first defined from bathymetric data (Arens 
et al., 1971), but are in fact related to basement highs. Our database highlights the great diversity of marginal ridges in terms of size (40 km to $200 \mathrm{~km}$ wide), morphology and structure. This diversity probably reflects different mechanisms of formation (Basile, 2015 and references therein).

We observed three main shapes for marginal ridge: the Exmouth marginal ridge (made of a thick sedimentary section, Figure 13K) and the Diaz marginal ridge of the Agulhas transform margin (basement ridge, Figure 13D) present a similar wide antiform structure. The Côte d'Ivoire-Ghana (Figure 13G) and Vøring (Figure 13H) marginal ridges are narrower $(20 \mathrm{~km})$. They consist of deformed sediments topped by a postdeformation unconformity, which is tilted continent-ward with a flexural shape, while the continental slope represents the ocean-ward side of the ridge. The inner FalklandsMalvinas and Demerara plateaus exemplify a last case with wide $(>150 \mathrm{~km})$ marginal ridges titled continent-ward (Figure 13A and I).

Marginal ridges are not systematically located in the same position (towards the inner or outer corners) along a transform margin. One can hypothesize that the vertical movements that built the marginal ridge can take place all along the transform margin, but that sub-aerial erosion may erase any topographic effect at shallow depths. The marginal ridge can be preserved from erosion only in a deep-sea setting, even if the crest of the ridge has been affected by shallow-water erosion as in the Côte d'IvoireGhana example (Basile et al., 1998). This erosion indicates that the ridge has been truly uplifted, and not only subjected to differential subsidence, with a less important subsidence along marginal ridge compared to the adjacent area. However, this hypothesis based on the Côte d'Ivoire-Ghana case may not be adequate for other examples. 
According to the literature, the development of marginal ridges is always associated with a phase of uplift along the transform border (Basile, 2015). The timing of this uplift depends on the model that is proposed (syn-transform when associated with transpression, crustal thickening, flexural uplift and erosional unloading, immediately post-transform when associated with thermal uplift).

Only one case study allows to date precisely this uplift and to relate it to a driving mechanism with some confidence: along the Côte d'Ivoire Ghana, the uplift began during the intracontinental transform stage and has been going on untill the passive stage, long time after the seafloor spreading ridge had swept along the margin. The model that fits best the timing and the shape of this marginal ridge relates to flexural uplift and erosional unloading (Basile \& Allemand 2005). In this same case study, it has been demonstrated that the post-deformation unconformity formed at sea level (Mascle et al., 1995) and is Albian in age, i.e it formed during the active transform stage. This unconformity was most probably initially horizontal and is now tilted toward the continent, recording post-albian vertical movements.

This result address two main questions that are fundamental for understanding vertical movements along transform margins:

(1) Does the post-deformation unconformity really correspond to a post-transform unconformity as stated theoretically (Basile, 2015)?

(2) Can we use this unconformity as a marker for vertical movements?

To answer the first question, we review the Côte d'Ivoire-Ghana case: there, the postdeformation unconformity has been proven to be diachronous but older than the end of the strike-slip displacement along the transform margin (Basile et al., 1998). This unconformity is thus older than the theoretical Post-Transform Unconformity (PTU), 
defined in Basile (2015). This may be due to the narrowing and migration of the deformation zone through time towards the continent-ocean boundary (Basile et al., 1998): strike-slip deformation stopped earlier far from the continent-ocean boundary. Furthermore, Bigot-Cormier et al. (2005) demonstrated in the Côte d'Ivoire-Ghana case that the erosion of the continental slope started during the active transform margin stage, but that subsequent retrogressive erosion erased any remnant of the younger PTU along the continental slope. In other words, along Côte d'Ivoire-Ghana, the postdeformation unconformity is diachronous and it probably prolongs towards the continental slope untill the last stages of transform activity. Then, it was eroded during the passive margin stage. To conclude, the post-deformation unconformity is not equal and should not be considered as the post-transform unconformity: the post-deformation unconformity visible on seismic lines is diachronous and older than the theoretical postdeformation unconformity itself probably erased by further erosion on the continental slope.

To answer the second question, the best way to investigate vertical movements is to use the shape of the post-deformation unconformity,that formed at sea level as demonstrated from drill holes for Demerara (Gouyet, 1988) and Côte d'Ivoire-Ghana (Mascle et al., 1995) or inferred from seismic data (Falkland-Malvinas: Lorenzo and Wessel, 1997). Therefore, a tilted unconformity indicates a differential subsidence and/or uplift after it formation. The continent-ward tilting observed in the inner part of the Falkland-Malvinas margin can be interpreted as uplift along the transform, similar to that at marginal ridges, but eroded (Figure 13A). The same interpretation can be proposed for the central part of the Côte d'Ivoire-Ghana margin (Figure 13F). However, it must be kept in mind that the fact that a post-deformation unconformity is tilted 
seaward or landward does not mean that this tilt postdates the active stage. As demonstrated by the Côte d'Ivoire-Ghana or Demerara examples, it could have happened during the active stage. To conclude, where it has been sampled, the postdeformation unconformity was demonstrated to be formed at sea level before the end of transform activity. Its shape can be used for estimating posterior vertical movements. However, distinguishing post-deformation vertical movements that occurred during the active stage from post-deformation vertical movements that occurred during the passive stage requires more advanced seismic and stratigraphic investigation.

Finally, it is noteworthy that the wavelength of this continent-ward tilt seems to be inversely proportional to the depth of the continental margin, which can be related to the thickness of the crust if isostatic equilibrium is assumed. The deeper the margin, the thinner the margin crust, the shorter the uplift wavelength is. Long wavelengths $(>100$ km) are observed for the central Côte d'Ivoire-Ghana (Figure 13F) and inner FalklandMalvinas (Figure 13A), while short wavelengths $(<20 \mathrm{~km})$ belong to the distal outer parts of Côte d'Ivoire-Ghana (Figure 13E) and Vøring (Figure 13H). This relationship, together with the concave shape of the unconformity, suggests in these cases, that the uplift mechanism is linked to flexure of the lithosphere.

\subsection{Marginal plateaus}

A second important result is the definition of a new bathymetric feature, the marginal plateaus, which are systematically bound on one side by a transform margin. Marginal plateaus are defined as flat and deep surfaces within the continental slope. All marginal ridges observed up to now are located along transform margins that comprise a marginal plateau (Figure 13 A, C, D, G, H, I, K), probably because the deep setting of 
marginal plateau favors the preservation of ridges from erosion. However, not all marginal plateaus display a marginal ridge.

Marginal plateaus occur in some cases at the outer intersection of a transform margin and a divergent margin. But in most cases, they are as long as the adjacent transform margin, and are located at the boundary between oceanic domains of different ages. Globally, one third of the identified transform margins present a deep marginal plateau. All marginal plateaus share a multi-stage evolution, with at least one period of rifting prior to transform formation. Few, as the Vøring plateau, are located within an oceanic domain, where divergent and transform margins formed together. Several periods of rifting occurred there since the Permian, before the final oceanic opening during the Tertiary (Mjelde et al., 2009). Most commonly, marginal plateaus are located at the intersection of two oceanic domains with contrasting ages (Figures 5 and 10):

- The Demerara and Guinea plateaus are located at the junction between the Central Atlantic (oceanic accretion initiated at $180 \mathrm{Ma}$ ) and the Equatorial Atlantic (initiation at $115 \mathrm{Ma}$ ). Those plateaus first underwent regional crustal thinning associated with the Jurassic Central Atlantic rifting (Greenroyd et al., 2008), then a Cretaceous transform deformation during the Cretaceous (Gouyet, 1988; Basile et al., 2013).

- Off South Australia, the South Tasman plateau is located between the Cretaceous Tasman Sea and the Tertiary Antarctic Ocean (Figures 2 and 5), similarly suggesting a first crustal thinning followed by transform margin formation during Eocene-Oligocene (Exon et al., 1997).

- The crust of the NorthEast Greenland plateau was thinned by several periods of rifting before the Eocene oceanic opening of the North Atlantic. After a plate kinematic rearrangment, the strait between Greenland and Svalbard opened, leading to the 
formation of two conjugate transform margins, a deep-sea plateau at the southern termination of the domain, and the formation of the Morris Jesup Rise and Yemark plateau at the northern termination (Engen et al., 2008).

Similar two-steps evolutions can be proposed for the Newfoundland, Falkland-Malvinas or Exmouth plateaus. In all these examples, the transform margin that bounds one side of the marginal plateau is located in the youngest oceanic domain. A rifting period followed by oceanic opening and divergent margin formation thus predates the transform opening. As a consequence of this thinning, isostatic compensation is likely to explain the bathymetry of these features, and these marginal plateaus should be considered as remnants of older rifted crust or divergent margins, cut by more recent transform faults.

When the oceanic opening followed the first phase of rifting, we determined the age gap between the two oceanic opening events using age floor model of Müller et al. (2008) (Table 3). The shorter age gaps (10 and $15 \mathrm{Ma}$ ) correspond to narrow marginal plateaus (and thus short activity transform margins) situated in the South Atlantic ocean (Brazil offshore and Walvis). A longer age gap of $65 \mathrm{Ma}$, which occurred between Central Atlantic and Equatorial openings, leads to the formation of Demerara and Guinea plateaus.

\subsection{Initiation of transform margins}

The plate kinematic setting is a first parameter that controls the initiation of transform margins. Some of the longest transform margins are located at the junction of two oceans of different age, such as the equatorial Atlantic transform margins at the junction between the Central and South Atlantic domains. The connection between these two 
domains induced in the equatorial Atlantic a regional obliquity between the trend of the incipient plate boundary and the opening direction between the African and South American plates. This regional obliquity may control the length and spacing of transform margins (Basile, 2015).

A second parameter that may influence the formation of transform margins is the inherited structure of the continental lithosphere. Some long transform margins can be related to onshore inheritance. For example, Attoh et al. (2005) proposed that an ancient PanAfrican suture zone localized the Côte d'Ivoire Ghana transform margin formation. On a larger scale, Thomas et al. (2005) showed that the pattern of transform and divergent margins succession is relatively stable during successive Wilson cycles.

A third of transform margins are bound marginal plateaus, interpreted as continental domains that were thinned 10 Myr (Maceio) to 65 Myr (Demerara and Guinea plateaus) before transform motion (Table 3). The time spans between the two opening events suggest a thermal control and a thickening of the lithospheric mantle by cooling. As a working hypothesis, we propose that thinned continental crusts associated with relatively thick lithospheric mantle may favour the formation of transform faults. Bonatti (1996) proposed that the cold thermal regime of the mantle could have played a major role in the opening of the equatorial Atlantic and controlled the development of long transform margins. In turn, hot conditions and thin lithospheric mantle are associated with mantle plumes, and to some extent to back-arc basins, that develop above former volcanic arcs. These conditions seem to prevent the localization of transform faults even in very oblique opening conditions, such as in the western part of the Gulf of Aden, close to the Afar hotspot. More generally, only few transform margins are associated with volcanic margins (Geoffroy, 2005), as 70\% of the transform margins 
we identified occur in non-volcanic domains. Those that occur in volcanic domains are shorter, with the exception of the Vøring transform margin.

Finally, this inventory also provides the first compilation of the lengths of transform continental margins. Those lengths are highly variable from 30 to $1300 \mathrm{~km}$, most frequently between 100 and $200 \mathrm{~km}$ (Figure 6). No transform margin shorter than 30 $\mathrm{km}$ was observed. This could be due to the resolution of the datasets, especially the synthetic ocean-continent boundary maps. In turn, it may be difficult for lithospheric transform faults to individualize over such short distances. For example, while according to this inventory the Gulf of Aden displays a first order segmentation leading to the formation of 40-100 km long transform margins segments, detailed studies show that a second-order segmentation (25 km) does exist (d'Acremont et al., 2004). However, this segmentation leads only to the formation of transfer zones that should not be considered as transform margins following our definition, as they did not superpose to an active, or previously active transform fault.

\subsection{Specific sedimentary processes}

The morphology and vertical displacements of transform margins may induce specific sedimentary processes. The main specificity of transform margins is related to the steepness of their continental slope that prevents any significant sediment build-up and favours gravity-driven collapses at different scales (Falklands: Dingle, 1977; French Guiana and Suriname: Loncke et al., 2009, Pattier et al., 2013, Loncke et al., in press; outer Guinea plateau: Rossi et al., 1992). The erosion of the steep continental slope allows deep parts of the pre and syn-rift sedimentary sections and continental basement to crop out (Falkland, Côte d'Ivoire-Ghana, Demerara, Voring Figures 13A, 13F and 13G, 
13I, $13 \mathrm{H}$, respectively). Deep geostrophic currents that contour the steep reliefs of transform margins may also favour submarine erosion (Rossi et al., 1992; Loncke et al., in press). However, in some transform margins, recent sediments are deposited on the continental slope. These examples are located close to large rivers (e.g. Amazon fan; Niger delta close to the Côte d'Ivoire-Ghana transform margin: Figure 13E), mainly in the inner corner of the transform margin.

The post-rift sedimentation can be relatively thick on transform margins close to marginal ridges that create a dam, preventing the transport of the sediment towards the deep basin. When the margin is tilted sea-ward, there is no marginal ridge, the sedimentation is less confined and the continental slope undergoes sedimentation similarly to divergent margins. However, the distal parts of marginal plateaus are located far from potential continental sediment sources. There, present-day sedimentation rates are low and strong contouritic currents have been evidenced (Demerara and Guinea plateau, Rossi et al., 2012, Tallobre et al., 2014, Loncke et al., in press). Those currents are responsible for the onset of mounded contourite deposits and may participate in the erosion of the continental slope.

\subsection{Variability of transform margins}

Several factors may explain the observed variability:

(1) Along-strike variability may result from the coalescence, in a single margin, of several strike-slip segments, that may represent transpressional or transtensional relays. This is for example the case in the northern Demerara transform margin, where the central part is a transtensional relay between strike-slip segments (Maillard et al., 2013; Loncke et al., in press). 
The effects of segmentation are expected to be more visible in long transform margins, such as the Agulhas or the Falklands-Malvinas transform margins. Furthermore, these long margins were active during a long period of time (50 Million years), and if plate kinematic changes occurred in this time, it may have influenced (by transtension or transpression) the active part of the margin.

(2) During passive margin stages, some transform margins (Guinea transform margin, Benkhelil et al., 1995; Agulhas transform margin) also experienced volcanism: volcanic seamounts are sometimes lined up with oceanic fracture zones and transform margins, which act as a lithospheric weakness zone (Deplus et al., 1998). Similarly, transform margins may be tectonically reactivated and localize intra-plate deformation (Attoh et al., 2005).

(3) Another factor of variability may lie in the inherited thickness or structure of the continental crust. This is probably the case for the marginal plateau of the Falkland-Malvinas margin (Figure 11), where the middle part of the transform margin is deeper, compared to shallower inner and outer corners.

(4) Finally, the ocean-ward or land-ward tilt of the margin and its post-deformation sediments may relate to the coupling of the continental margin with the oceanic lithosphere across the transform fault. During the active transform stages (intracontinental or active margin stages, cf. Basile, 2015), the transform fault can be expected to be a low friction contact between two lithospheric plates, allowing each one to move vertically independently. During this stage, unloading of the steep continental slope by erosion would cause the uplift of the continent edge decoupled from the oceanic slab, which in turn would amplify the erosion (Basile and Allemand, 2002). On the contrary, during the passive margin stage, the two 
plates are expected to be coupled across the inactive transform fault, i.e. to have the same vertical movement at the continent-ocean boundary. In this case, the thermal subsidence of the oceanic plate should induce a late downward and ocean-ward flexure of the continental margin (Lorenzo and Wessel, 1997). Some margins seem to show evidence of such late ocean-ward flexure (inner FalklandMalvinas, Figure 13A; central Côte d'Ivoire-Ghana, Figure 13F; and at a smaller scale outer Côte d'Ivoire-Ghana, Figure 13E).

\section{Conclusions}

In this paper, we present a comprehensive database of transform continental margins, mainly from the comparison of oceanic fracture zones with continent-ocean boundary maps. We identified 78 transform continental margins, to be compared to the 25 transform margins listed previously by Scrutton (1982) or 29 identified by Lorenzo (1997). Their length ranges from 45 to $1300 \mathrm{~km}$, reflecting huge variations in the duration of the tectonic activity of the transform margin, from less than 5 to more then 50 Myr. In length, transform margins represent $16 \%$ of all continental margins and $31 \%$ of non-convergent continental margins.

Prior to this compilation, transform margins were characterized, based on only a few case studies, as having steep continental slopes, narrow necking zone in the transition between continent and ocean, and a marginal ridge at the edge of the continental slope. The new database we present allowed us to evaluate these assumptions. The main result from this study is that transform margins present a vast variability, and that what was thought to characterize these margins does not necessarily present a systematic character: 
- even if steeper on average when compared to divergent margins, the continental slope can be quite gentle in some transform margins, in a range similar to divergent margins. The steepest slopes, sometimes higher than $10^{\circ}$, are eroded and devoid of sediments, while the sediments prograde on the more gentle slopes.

- When known, the width of continental crust necking zone is a good indication for the identification of a transform margin. It is always significantly narrower than for divergent margins, ranging from 50 to $100 \mathrm{~km}$, reflecting the deformation in a subvertical transform fault.

- Marginal ridges parallel to the continent-ocean boundary are specific to transform margins, but can be observed only in few transform margins (table 1). However, subaerial erosion may have removed these ridges in the shallow parts of some of the margins, which may lead to an underestimation of their occurrence. We observed three types of marginal ridges, either a wide $(50 \mathrm{~km})$ symmetric anticlinorium, a narrow (20 $\mathrm{km}$ ) asymmetric flexural ridge, or a very wide $(150 \mathrm{~km})$ continent-ward tilted crust. Flexural ridges can be related to unloading of the lithospheric plate by erosion along the continental slope.

- The marginal plateau, although previously recognised, is a new bathymetric feature associated with transform margins, which we define as deep and flat surfaces within the continental slope. Marginal plateaus are specific to transform margins, as they are always bound on one side by a transform margin. But they are note systematic, as they are observed only for a third of the transform margins. Marginal plateaus are interpreted as thin continental crust domains inherited from a stretching event older than the formation of the transform margin. 
At the regional scale, initiation of transform margins can be related to the connection of propagating oceanic domains, and especially to the connection of two domains positioned in a step-over. Locally, inherited structures, such as suture zones or preexisting faults can localize the transform motion, but it seems that lithospheric structure may prevail in the location of transform faults. Only few transform margins are located in areas affected by a thermal event, as above a hot spot or in back-arc basins, while they often occur in areas where the lithospheric mantle can be assumed to be thicker, such as in marginal plateaus. Variability of transform margins can be related to these inherited structures, but also to segmentation that can result from the coalescence, in a single margin, of pure strike slip segments alternating with transpressional and transtensional bends.

Most transform margins display a regional diachronous unconformity that seals strikeslip deformation. In most cases, this unconformity looks as a wave-cut surface, initially horizontal. Therefore, the shape of the unconformity is an excellent tool for estimating further relative vertical movements, that can be either upward as in flexural marginal ridges that are tilted towards the continent, or downward as many transform margins present an increasing subsidence of the post-deformation unconformity towards the ocean.

Finally, some specific sedimentary processes are associated with transform margins. Because of the frequent steepness of the continental slope, erosional processes, slope instabilities and contourites are common along those margins. When present, marginal ridges play the role of a dam for sediments, confining thick depocenters. On the 
contrary, transform margins along marginal plateaus typically show extremely low sedimentation rates, due to their large distance from emerged continent.

\section{Acknowledgements}

We thank TOTAL and the ANRT for funding Marion Mercier de Lépinay's PhD thesis and the French program "Action Marges" for supporting this work. We also deeply thank Carole Boukandou Sidi and Marc Vanhaesebroucke for their work on the bathymetric analysis of transform margins. We are grateful to Susanne Buiter, Peter Japsen, and three anonymous reviewers for their constructive comments that helped improve this manuscript. We also thank Virginie Gaullier for her useful remarks during the initial stages of this work.

The bathymetric maps were generated using the Geomapapp application (http://www.geomapapp.org, 2013 July 9) and the Global Multi-Resolution Topography (GMRT) Synthesis (Ryan et al., 2009).

\section{References}

Amante, C. and Eakins, B. W., 2009. ETOP01 1 Arc-Minute Global Relief Model: Procedures, Data Sources and Analysis. NOAA Technical Memorandum NESDIS NGDC-24, pp. 19

Antobreh, A. A.; Faleide, J. I.; Tsikalas, F. and Planke, S., 2009. Rift-shear architecture and tectonic development of the Ghana margin deduced from multichannel seismic reflection and potential field data. Marine and Petroleum Geology 26, 345-368 
Arens, G., Delteil, J. R., Valery, P., Damotte, B., Montadert L. and Patriat P., 1971. The continental margin of the Ivory Coast and Ghana F.M. Delany (Ed.), The Geology of the East Atlantic Continental Margin, Rep. 70/16, Vol. 4, Africa. Inst. Geol. Sci, London , pp. 61-78

Attoh, K., Larry, B. and Haelein, J., 2005. The role of Pan-African structures in intraplate seismicity near the termination of the Romanche fracture zone, West Africa. Journal of African Earth Sciences 43, 549-555

Basile, C., 2015. Transform continental margins - Part 1 : Concepts and models. Tectonophysics, 661, 1-10.

Basile, C. and Allemand, P., 2002. Erosion and flexural uplift along transform faults. Geophysical Journal International 151, 646-653

Basile, C., Mascle, J., Popoff, M., Bouillin, J.P., and Mascle, G., 1993. The Côte d'IvoireGhana transform margin: a marginal ridge structure deduced from seismic data. Tectonophysics 222, 1-19.

Basile, C.; Mascle, J.; Benkhelil, J. and Bouillin, J.-P., 1998. 11. Geodynamic Evolution of the Côte d'Ivoire-Ghana Transform Margin : an overview of leg 159 results. Proceedings of The Ocean Drilling Program, Scientific Results 159

Basile, C.; Mascle, J. and and Guiraud, R., 2005. Phanerozoic geological evolution of the Equatorial Atlantic domain. Journal of African Earth Sciences 43, 27-282

Basile, C.; Maillard, A.; Patriat, M.; Gaullier, V.; Loncke, L.; Roest, W.; Mercier de Lépinay, M. and Pattier, F., 2013. Structure and evolution of the Demerara Plateau, offshore French Guiana: Rifting, tectonic inversion and post-rift tilting at transform-divergent margins intersection. Tectonophysics 591, 1629 
Ben-Avraham, Z.; Hartnady, C. and Malan, J., 1993. Early tectonic extension between the Agulhas Bank and the Falkland Plateau due to the rotation of the Lafonia microplate. Earth and Planetary Science Letters 117, 43-58

Ben-Avraham, Z.; Hartnady, C. J. H. and Kitchin, K. A., 1997. Structure and tectonics of the Agulhas-Falkland fracture zone. Tectonophysics 282, 83-98

Benkhelil, J., Mascle, J. and Tricart, P., 1995. The Guinea continental margin: an example of a structurally complex transform margin. Tectonophysics, 248, 117-137

Berndt, C.; Mjelde, R.; Planke, S.; Shimamura, H. and Faleide, J. I., 2001. Controls on the tectono-magmatic evolution of a volcanic transform margin : the Vøring Transform margin. Marine Geophysical Researches 22, 133-152.

Bigot-Cormier, F., Basile, C., Poupeau, G., Bouillin, J.P. and Labrin, E., 2005. Denudation of the Côte d'Ivoire-Ghana transform continental margin from apatite fission tracks. Terra Nova, 17, 189-195.

Bird, D., 2001. Shear margins : continent-ocean transform and fracture zone boundaries. The Leading Edge 20, 2, 150-159.

Bonatti, E., 1996. Anomalous opening of the Equatorial Atlantic due to an equatorial mantle thermal minimum. Earth and Planetary Science Letters $143,147-160$.

Breivik, A. J., Mjelde, R., Grogan, P., Shimamura, H., Murai, Y. and Nishimura, Y., 2003. Crustal structure and transform margin development south of Svalbard based on ocean bottom seismometer data. Tectonophysics, 369, 1-2, 37-70. 
Bull, J. M. and Masson, D. G., 1996. The southern margin of the Rockall Plateau: stratigraphy, Tertiary volcanism and plate tectonic evolution. Journal of the Geological Society 153, 601-612

Chand, S., Radhakrishna, M. and Subrahmanyam, C., 2001. India-East Antarctica conjugate margins: rift-shear tectonic setting inferred from gravity and bathymetry data. Earth and Planetary Science Letters 185, 225-236

Cobbold, P. R., Clarke, B. J., and Løseth, H., 2009. Structural consequences of fluid overpressure and seepage forces in the outer thrust belt of the Niger Delta. Petroleum Geoscience 15, 3-15.

Curray, J. R., 2005. Tectonics and history of the Andaman Sea region. Journal of Asian Earth Sciences 25, 187-232

Czuba, W., Grad, M., Mjelde, R., Guterch, A., Libak, A., Krüger, F., Murai, Y., Schweitzer, J. and the IPY Project Group, 2011. Continent-ocean-transition across a trans-tensional margin segment: off Bear Island, Barents Sea Geophysical Journal International 184, 541-554

d'Acremont, E.; Leroy, S.; Beslier, M.-O.; Bellahsen, N.; Fournier, M.; Robin, C.; Maia, M. andand Gente, P., Structure and evolution of the eastern Gulf of Aden conjugate margins from seismic reflection data. Geophysical Journal International, Blackwell Science Ltd, 2005, 160, 869-890

Dailly, P., Henderson, T., Hudgens, E., Kanschat, K., and Lowry, P., 2013. Exploration for Cretaceous stratigraphic traps in the Gulf of Guinea, West Africa and the discovery of the Jubilee Field: a play opening discovery in the Tano Basin, Offshore Ghana. Geological Society, London, Special Publications 369, 235248. 
de Caprona, G. C., 1992. The continental margin of western Côte d'Ivoire: structural framework inherited from intra-continental shearing. PhD thesis, pp150, Université Pierre et Marie Curie, Paris 6, Paris

Deplus, C., Diament, M., Hébert, H., Bertrand, G., Dominguez, S., Dubois, J., Malod, J., Patriat, P., Pontoise, B. and Sibilla, J. J., 1998. Direct evidence of active deformation in the eastern Indian oceanic plate. Geology 2, 131-134

Dingle, R. V., 1977. The anatomy of a large submarine slump on a sheared continental margin (SE Africa). Journal of the Geological Society 134, 293-310

Direen, N. G., Borissova, I., Stagg, H. M. J., Colwell, J. B. and Symonds, P. A., 2007. Nature of the continent-ocean transition zone along the southern Australian continental margin: a comparison of the Naturaliste Plateau, SW Australia, and the central Great Australian Bight sectors . Geological Society, London, Special Publications 282, 239-263

Direen, N. G.; Stagg, H. M. J.; Symonds, P. A. and Colwell, J. B., 2008. Architecture of volcanic rifted margins: new insights from the Exmouth - Gascoyne margin, Western Australia. Australian Journal of Earth Sciences 55, 341-363

Døssing, A., Stemmerik, L., Dahl-Jensen, T. and Schlindwein, V., 2010. Segmentation of the eastern North Greenland oblique-shear margin -- Regional plate tectonic implications. Earth and Planetary Science Letters 292, 239-253

Døssing, A., and Funck, T., 2012. Greenland Fracture Zone-East Greenland Ridge (s) revisited: Indications of a C22-change in plate motion? Journal of Geophysical Research: Solid Earth 117, B1.

Engen, Ø.; Faleide, J. I. \& Dyreng, T. K., 2008. Opening of the Fram Strait gateway: A review of plate tectonic constraints. Tectonophysics 450, 51-69 
Exon, N. F.; Vonrad, U. and Vonstackelberg, U., 1982. The Geological Development of the Passive Margins of the Exmouth Plateau Off Northwest Australia. Marine Geology, Elsevier Science Bv 47, 131-152

Exon, N. F., Berry, R. F., Crawford, A. J., and Hill, P. J., 1997. Geological evolution of the East Tasman Plateau, a continental fragment southeast of Tasmania. Australian Journal of Earth Sciences 44, 597-608.

Exxon World Mapping Project, 1985. Tectonic Map of the World. Exxon Production Research Company, Houston, USA.

Francheteau, J. and Le Pichon, X. 1972., Marginal Fracture Zones as Structural Framework of Continental Margins in South Atlantic Ocean. AAPG bulletin 56, 991-1007

Funck, T., Jackson, H. R., Louden, K. E. and Klingelhöfer, F., 2007. Seismic study of the transform-rifted margin in Davis Strait between Baffin Island (Canada) and Greenland: What happens when a plume meets a transform. J. Geophys. Res. 112, B04402-

Geoffroy, L., 2005. Volcanic passive margins. Comptes Rendus Geoscience 337, 16, 1395-1408. doi: 10.1016/j.crte.2005.10.006.

Gernigon, L., Olesen, O., Ebbing, J., Wienecke, S., Gaina, C., Mogaard, J. O., Sand, M. and Myklebust, R., 2009. Geophysical insights and early spreading history in the vicinity of the Jan Mayen Fracture Zone, Norwegian-Greenland Sea. Tectonophysics 468, 185-205

Gibbons, A. D., Whittaker, J. M., and Müller, R. D., 2013. The breakup of East Gondwana: Assimilating constraints from Cretaceous ocean basins around 
India into a best-fit tectonic model. J. Geophys. Res. Solid Earth 118, 808-822. doi:10.1002/jgrb.50079.

Goncharov, A. and Nelson, G., 2012. From two way time to depth and pressure for interpretation of seismic velocities offshore: Methodology and examples from the Wallaby Plateau on the West Australian margin. Tectonophysics 572, 2637

Gonthier, E., Faugères, J.C., Gervais, A., Ercilla, G., Alonso, B. and Baraza, J., 2002. Quaternary sedimentation and origin of the Orinoco sediment-wave filed on the Demerara continental rise (NE margin of South America). Marine Geology $192,189-214$

Gouyet, S., 1988. Évolution tectono-sédimentaire des marges guyanaise et nordbrésilienne au cours de l'évolution de l'Atlantique Sud. PhD thesis, $374 \mathrm{pp}$, Université de Pau et des pays de l'Adour, Pau

Green, A., 2011. The late Cretaceous to Holocene sequence stratigraphy of a sheared passive upper continental margin, northern KwaZulu-Natal, South Africa. Marine Geology 289, 17-28

Greenroyd, C. J., Peirce, C., Rodger, M., Watts, A. B. and Hobbs, R. W., 2007. Crustal structure of the French Guiana margin, West Equatorial Atlantic. Geophysical Journal International 169, 964-987

Greenroyd, C. J.,; Peirce, C.,; Rodger, M.,; Watts, A. B. and Hobbs, R. W., 2008. Demerara Plateau - the structure and evolution of a transform passive margin. Geophysical Journal International, 172, 549-564 
Guiraud, M., Mascle, J., Benkhelil, J., Basile, C., Mascle, G. and Durand, M., 1997, Early Cretaceous deltaic sedimentary environnment of the Ivory Coast-Ghana transform margin as deduced om deep dives data. Geo. Mar. Lett. 17, 79-86.

Guiraud, M., Buta-Neto, A. and Quesne, D., 2010. Segmentation and differential post-rift uplift at the Angola margin as recorded by the transform-rifted Benguela and oblique-to-orthogonal-rifted Kwanza basins . Marine and Petroleum Geology 27, 1040 - 1068

Harry, D.; Londono, J. and Huerta, A., 2003. Early Paleozoic transform-margin structure beneath the Mississippi coastal plain, southeast United States. Geology 31, 969-972

Hernández-Molina, F.; Paterlini, M.; Somoza, L.; Violante, R.; Arecco, M.; de Isasi, M.; Rebesco, M.; Uenzelmann-Neben, G.; Neben, S. and Marshall, P., 2010. Giant, mounded drifts in the Argentine Continental Margin: Origins, and global implications for the history of thermohaline circulation. Marine and Petroleum Geology 27, 1508-1530

Jackson, H., Faleide, J. I. and Eldholm, 0., 1990. Crustal structure of the sheared southwestern Barents Sea continental margin. Marine Geology 93, 119 - 146

Keen, C.; Kay, W. and Roest, W. R., 1990. Crustal anatomy of a transform continental margin. Tectonophysics $173,527-544$

Labails, C., Olivet, J.L., Aslanian, D. and Roest, W. R., 2010. An alternative early opening scenario for the Central Atlantic Ocean. Earth and Planetary Science Letters 297, 355-368. doi: 10.1016/j.epsl.2010.06.024.

Leroy, S., Lucazeau, F., d'Acremont E., Watremez, L., Autin, J., Rouzo, S., Bellahsen, N., Tiberi, C., Ebinger, C., Beslier, M.-O., Perrot, J., Razin, P., Rolandone, F., 
Sloan, H., Stuart, G., Al Lazki, A., Al-Toubi, K., Bache, F., Bonneville, A., Goutorbe, B., Huchon, P., Unternehr, P. and Khanbari, K., 2010. Contrasted styles of rifting in the eastern Gulf of Aden: A combined wide-angle, multichannel seismic, and heat flow survey. Geochem. Geophys. Geosyst. 11, Q07004-

Libak, A., Eide, C. H., Mjelde, R., Keers, H. and Flüh, E. R., 2012. From pull-apart basins to ultraslow spreading : Results from the western Barents Sea Margin. Tectonophysics 514-517, 44-61

Loncke L. and the IGUANES scientific party, in press. Structure of the Demerara passive transform margin and associated sedimentary processes. Initial results from the IGUANES cruise. Special Publication on Transform Margins : Development, Controls and Petroleum Systems, ed. Michal Nemcok. Geological Society of London.

Lorenzo, J.M., 1997. Sheared continent-ocean margins: an overview. Geo-Marine Letters 17, 1-3.

Lorenzo, J. M. and Vera, E., 1992. Thermal uplift and erosion across the continentocean transform boundary of the southern Exmouth Plateau. Earth and Planetary Science Letters 108, 79 - 92

Lorenzo, J. M. and Wessel, P., 1997. Flexure across a continent-ocean fracture zone: the northern Falkland/Malvinas Plateau, South Atlantic. Geo-Marine Letters, Springer Berlin / Heidelberg 17, 110-118

Maillard, A., Basile C., Loncke L., Mercier de Lépinay M., Graindorge D., Heuret, A. and IGUANES scientific party, nov 2013. Premiers résultats de la campagne Iguanes : la marge transformante du Nord du plateau de Demerara (Guyane- 
Surinam). 14ème congrès de sédimentologie, Association des Sédimentologistes Français, Paris

Marks, K. M. \& Tikku, A. A., 2001. Cretaceous reconstructions of East Antarctica, Africa and Madagascar Earth and Planetary Science Letters 186, 479-495

Mascle, J., 1976. Atlantic-type continental margins - Distinction of 2 basic structural types. Anais da Academia Brasileira de Ciencias 48, 191-197.

Mascle, J. and Blarez, E., 1987. Evidence for transform margin evolution from the Ivory Coast-Ghana continental margin. Nature 326, 378-381

Mascle, J., Lohmann, G.P., and Moullade, M. (Eds.), 1995. Proc. ODP, Sci. Results, 159: College Station, TX (Ocean Drilling Program).

Matthews, K.J., Müller, R.D., Wessel, P. and Whittaker, J.M., 2011. The tectonic fabric of the ocean basins. Journal of Geophysical Research 116, B12109. doi:10.1029/2011JB008413.

Minshull, T.A., 2009. Geophysical characterisation of the ocean-continent transition at magma-poor rifted margins. Comptes Rendus Geosciences 341, 5, p. 382-393. doi: 10.1016/j.crte.2008.09.003.

Mjelde, R., Faleide, J., Breivik, A. and Raum, T., 2009. Lower crustal composition and crustal lineaments on the Vøring Margin, NE Atlantic: A review. Tectonophysics, Deep seismic profiling of the continents and their margins $472,183-193$

Mougenot, D., Gennesseaux, M., Hernandez, J., Lepvrier, C., Malod, J.-A., Raillard, S., Vanney, J.-R. and Villeneuve, M., 1991. La ride du Mozambique (Océan Indien): un fragment continental individualisé lors du coulissement de 
l'Amérique et de l'Antarctique le long de l'Afrique de l'Est? . Comptes rendus de l'Académie des sciences 312, 655-662

Moulin, M., Aslanian, D. and Unternehr, P., 2010. A new starting point for the South and Equatorial Atlantic Ocean. Earth-Science Reviews 98, 1 - 37

Müller, R.D., Sdrolias, M., Gaina, C. and Roest, W.R., 2008. Age, spreading rates, and spreading asymmetry of the world's ocean crust. Geochem. Geoph. Geosyst. 9, Q04006, doi:10.1029/2007GC001743.

Oakey, G. N. and Chalmers, J. A., 2012. A new model for the Paleogene motion of Greenland relative to North America: Plate reconstructions of the Davis Strait and Nares Strait regions between Canada and Greenland. J. Geophys. Res. 117, B10401-

Parsiegla, N.; Stankiewicz, J.; Gohl, K.; Ryberg, T. and Uenzelmann-Neben, G., 2009. Southern African continental margin: Dynamic processes of a transform margin. Geochem. Geophys. Geosyst. 10, Q03007

Pattier, F.; Loncke, L.; Gaullier, V.; Basile, C.; Maillard, A.; Imbert, P.; Roest, W.; Vendeville, B.; Patriat, M. andand Loubrieu, B., 2013. Mass-transport deposits and fluid venting in a transform margin setting, the eastern Demerara Plateau (French Guiana). Marine and Petroleum Geology 46, 287-303

Pindell, J. L., and Lorcan Kennan, 2001. Kinematic evolution of the Gulf of Mexico and Caribbean. In Transactions of the Gulf Coast Section Society of Economic Paleontologists and Mineralogists (GCSSEPM) 21st Annual Bob F. Perkins Research Conference, Petroleum Systems of Deep-Water Basins, Houston, Texas, December, pp. 2-5. 
Porter-Smith, R.; Lyne, V.; Kloser, R. and Lucieer, V., 2012. Catchment-based classification of Australia's continental slope canyons. Marine Geology 303, 183-192. doi : 10.1016/j.margeo.2012.01.008.

Raum, T.; Mjelde, R.; Shimamura, H.; Murai, Y.; Bråstein, E.; Karpuz, R.; Kravik, K. andand Kolstø, H., 2006. Crustal structure and evolution of the southern Vøring Basin and Vøring Transform Margin, NE Atlantic. Tectonophysics 415, $167-202$

Reid, I. 1988. Crustal Structure beneath the southern Grand Banks :seismic refraction results and their implications. Canadian Journal of Earth Science $25,760-772$

Royer, J.-Y. and Rollet, N., 1997. Plate-tectonic setting of the Tasmanian region. Australian Journal of Earth Sciences 44, 543-560

Rey, S. S., Planke, S., Symonds, P. A. and Faleide, J. I., 2008. Seismic volcanostratigraphy of the Gascoyne margin, Western Australia. Journal of Volcanology and Geothermal Research 172, 112 - 131

Reid, I. and Jackson, H. R., 1997. Crustal structure of northern Baffin Bay: Seismic refraction results and tectonic implications. J. Geophys. Res. 102, 523-542

Rodger, M., Watts, A., Greenroyd, C., Peirce, C. and Hobbs, R., 2006. Evidence for unusually thin oceanic crust and strong mantle beneath the Amazon Fan Geology 34, 1081-1084

Rossi S., Westall F. and Mascle J., 1992. The geomorphology of the Southwest Guinea Margin: tectonic, volcanic, mass movement and bottom current influences. Marine Geology 105, 225-240. 
Rouby, D.; Braun, J.; Robin, C.; Dauteuil, O. and Deschamps, F., 2013. Long-term stratigraphic evolution of Atlantic-type passive margins: A numerical approach of interactions between surface processes, flexural isostasy and 3D thermal subsidence. Tectonophysics 604, 83-103.

Ryan, W. B. F., Carbotte, S. M., Coplan, J. O., O'Hara, S., Melkonian, A., Arko, R., Weissel, R. A., Ferrini, V., Goodwillie, A., Nitsche, F., Bonczkowski, J. and Zemsky, R., 2009. Global Multi-Resolution Topography synthesis. Geochem. Geophys. Geosyst., 10, Q03014, doi:10.1029/2008GC002332.

Sage, F.; Basile, C.; Mascle, J.; Pontoise, B. and Whitmarsh, R. B., 2000. Crustal structure of the continent-ocean transition off the Côte d'Ivoire-Ghana transform margin: implications for thermal exchanges across the palaeotransform boundary. Geophysical Journal International 143, 662-678.

Scrutton, R.A., 1979. On sheared passive continental margins. Tectonophysics 59, 293-305.

Scrutton, R.A., 1982. Crustal structure of sheared passive continental margin. Geodynamics Series - Dynamics of passive margins 6, 133-139.

Seiler, C., Gleadow, A. J., Fletcher, J. M. and Kohn, B. P., 2009. Thermal evolution of a sheared continental margin: Insights from the Ballenas transform in Baja California, Mexico. Earth and Planetary Science Letters 285, 61 - 74.

Storti, F., Salvini, F., Rossetti, F. and Morgan, J. P., 2007. Intraplate termination of transform faulting within the Antarctic continent. Earth and Planetary Science Letters 260, $115-126$.

Tallobre, C., Giresse, P., Loncke, L., Bayon, G., Bassetti, M.-A., Randla, M., Buscail, R., Durrieu de Madron, X., Bourrin, F., Kunesch, S., Sotin, C., Serge, B. and 
Vanhaesebroucke, M., 2014. New findings of contourite-related structures and their implications on oceanographic and sedimentary conditions on the Demerara Plateau (French Guiana and Surinam). Abstracts. Presented at 2nd Deep water circulation congress: the contourite log-book, 10-12 September 2014, Ghent, Belgium.

Taylor, B., Goodliffe, A. and Martinez, F., 2009. Initiation of transform faults at rifted continental margins. Comptes Rendus Geosciences 341, 428 - 438

ten Brink, U. S., Coleman, D. F. and Dillon, W. P., 2002. The nature of the crust under Cayman Trough from gravity. Marine and Petroleum Geology 19, 971-987

Thomas, R., von Veh, M. and McCourt, S., 2005. The tectonic evolution of southern Africa: an overview. Journal of African Earth Sciences (and the Middle East). Geology and Development in Southern Africa 16, 5-24

Turner, J. P., Rosendahl, B. R. and Wilson, P. G., 2003. Structure and evolution of an obliquely sheared continental margin: Rio Muni, West Africa. Tectonophysics $374,41-55$

Uenzelmann-Neben, G. and Huhn, K., 2009. Sedimentary deposits on the southern South African continental margin: Slumping versus non-deposition or erosion by oceanic currents? Marine Geology 266, 65-79

Veevers, J. J., and M. W. McElhinny, 1976. The separation of Australia from other continents. Earth-Science Reviews 12, 2, 139-143. doi: 10.1016/0012$8252(76) 90003-9$

Vérard, C., Flores, K. and Stampfli, G., 2012. Geodynamic reconstructions of the South America-Antarctica plate system. Journal of Geodynamics 53, 43-60 
Watts, A. B., Rodger, M., Peirce, C., Greenroyd, C. J. and Hobbs, R. W., 2009. Seismic structure, gravity anomalies, and flexure of the Amazon continental margin, NE Brazil. J. Geophys. Res. 114, B07103- 


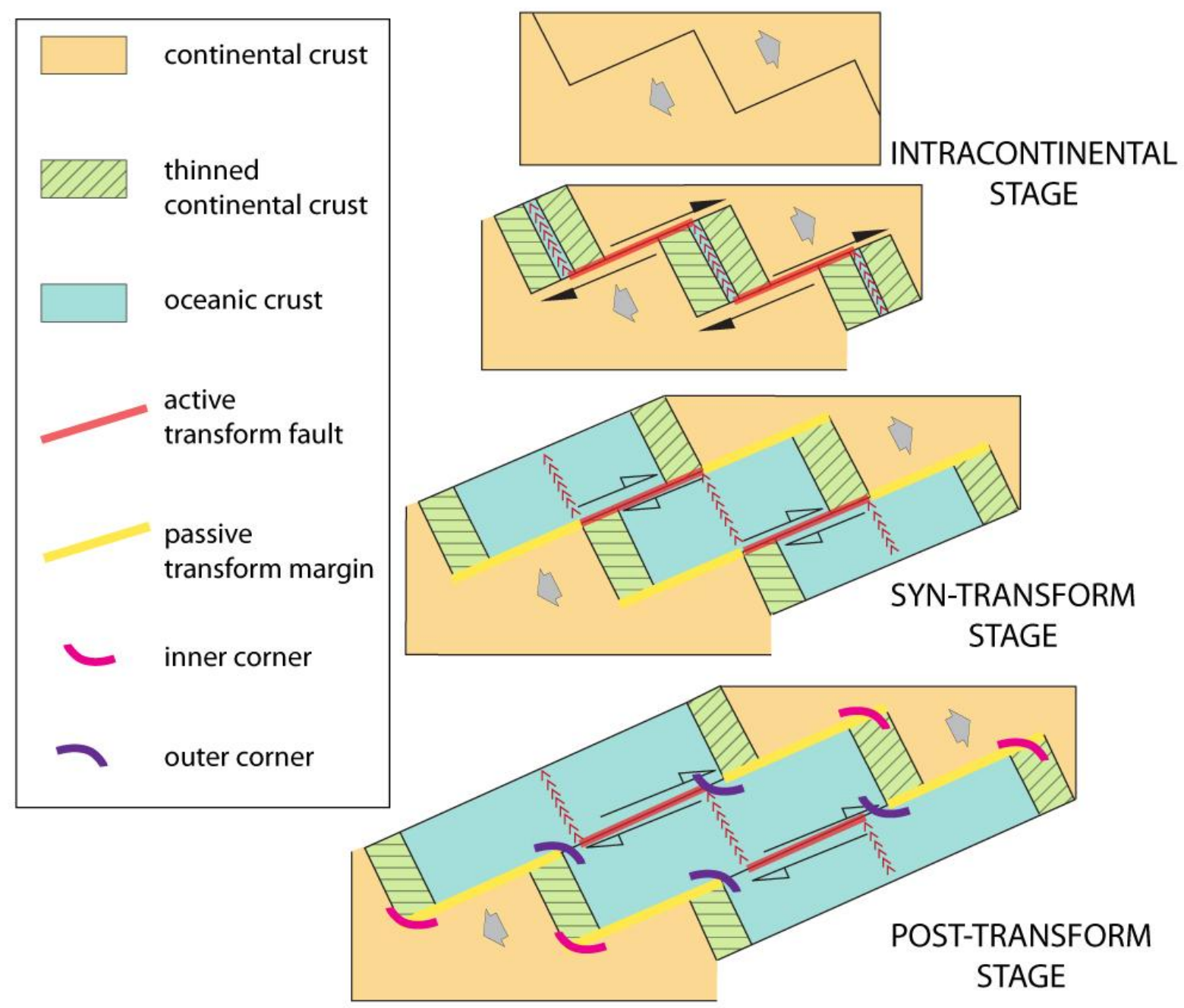

Fig. 1 

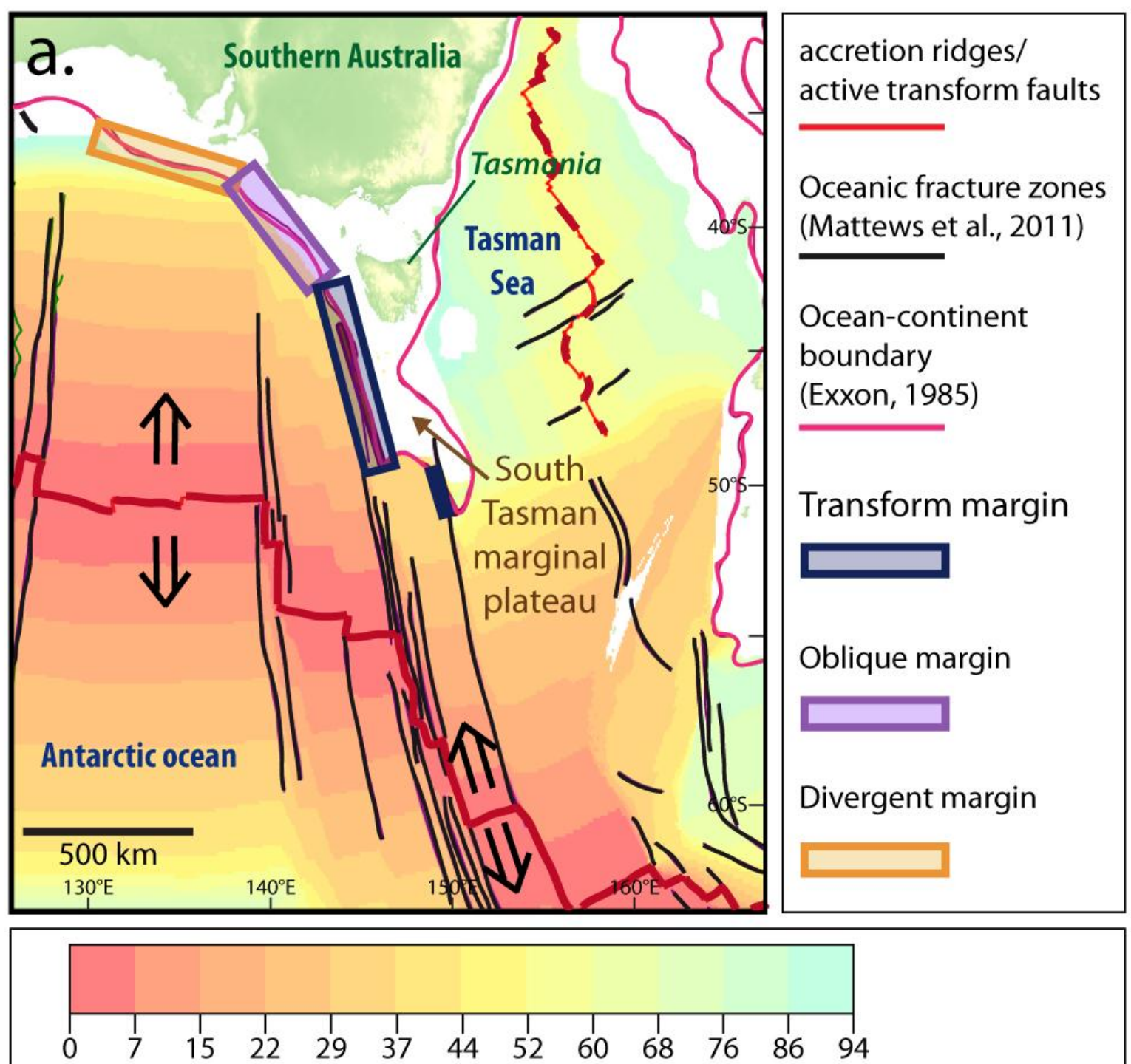

oceanic floor age (Ma) from Müller et al., 2008

Fig. 2 


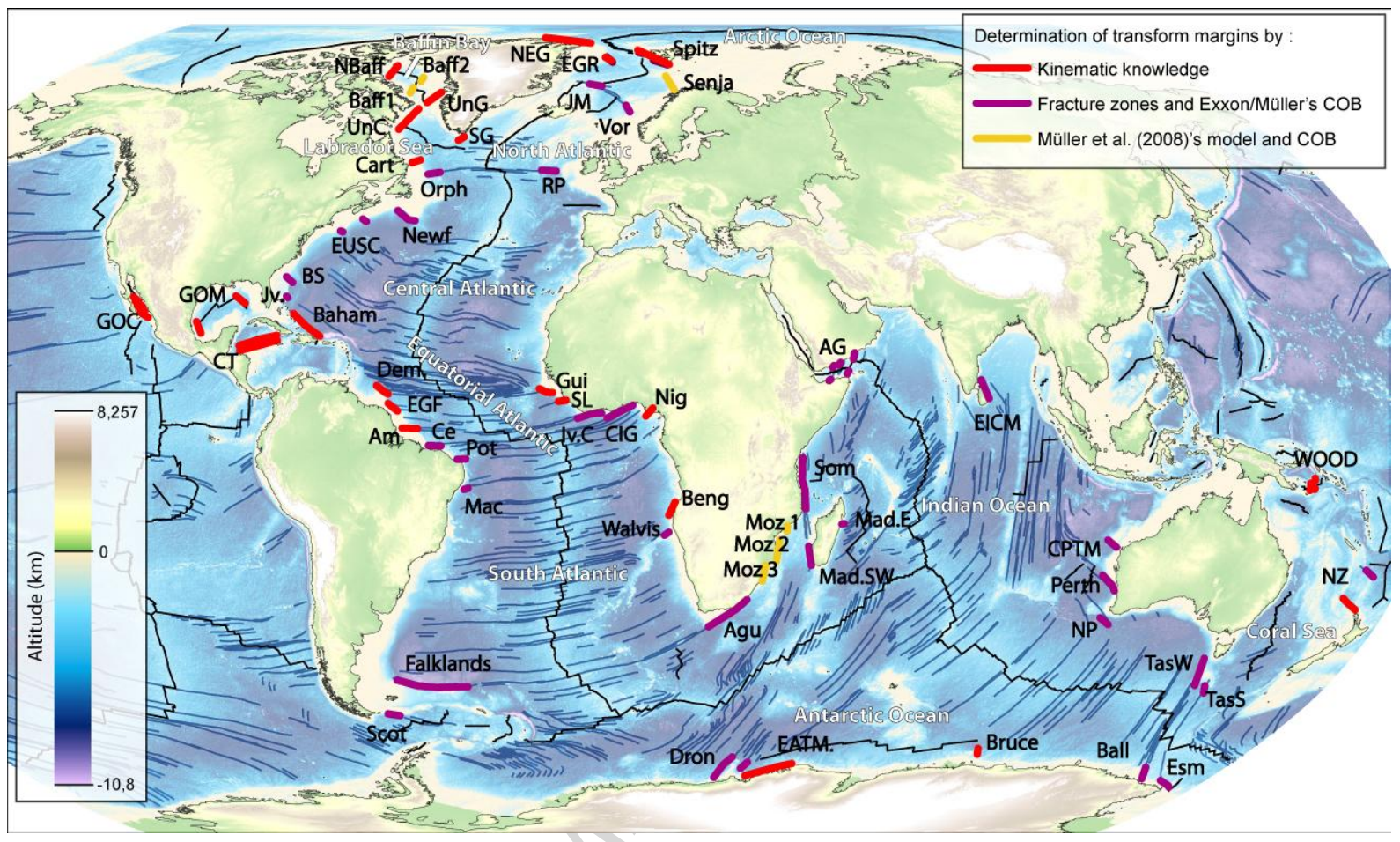

Fig. 3 


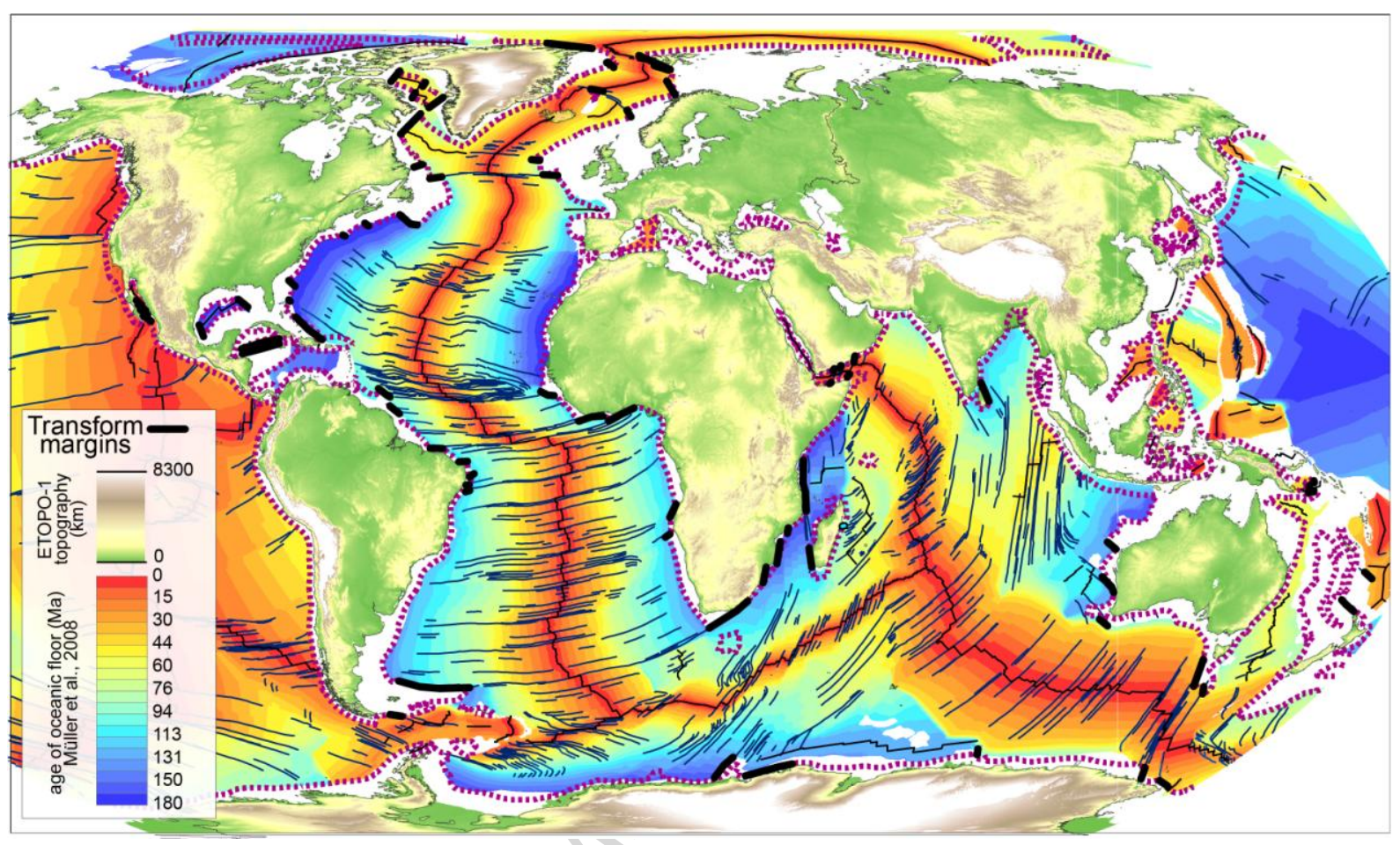

Fig. 4 


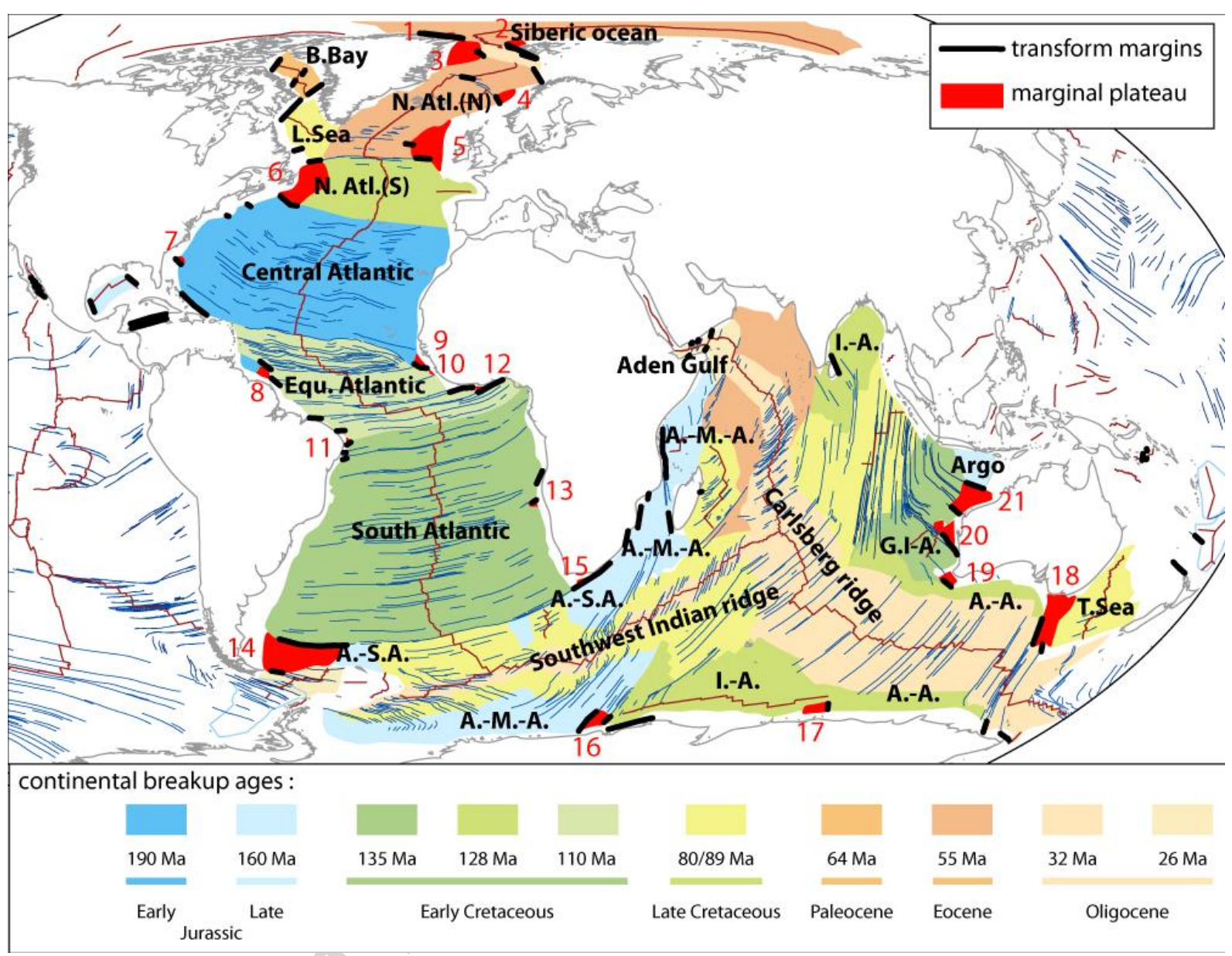

Fig. 5 
A.

TRANSFORM MARGINS LENGTHS

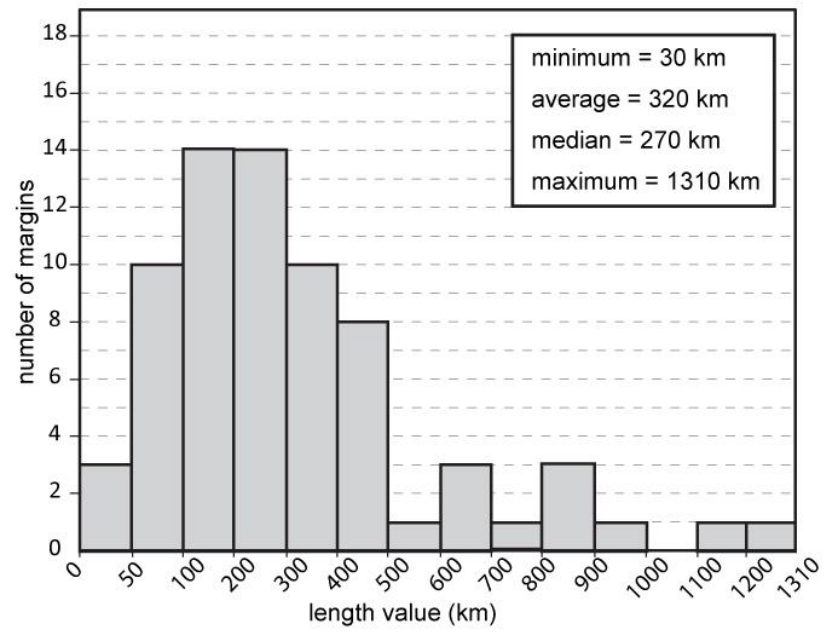

B. TRANSFORM MARGINS DURATION

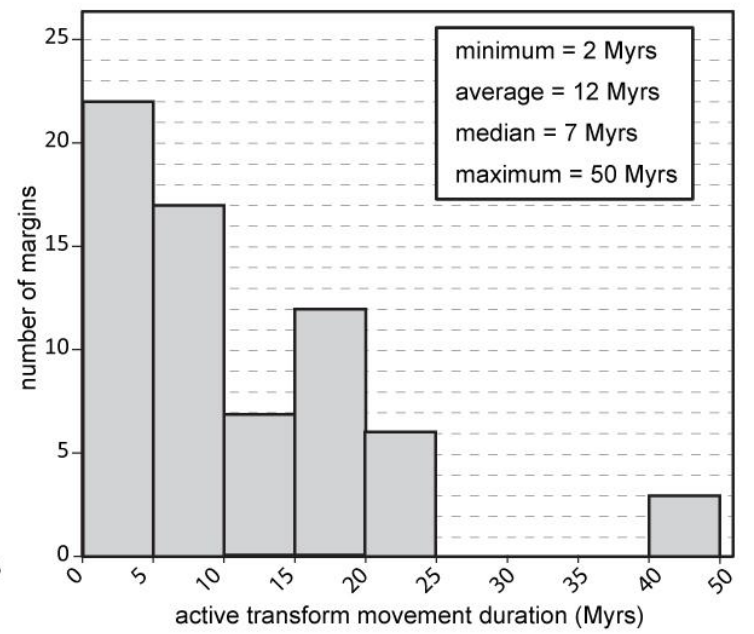

Fig. 6 
a.

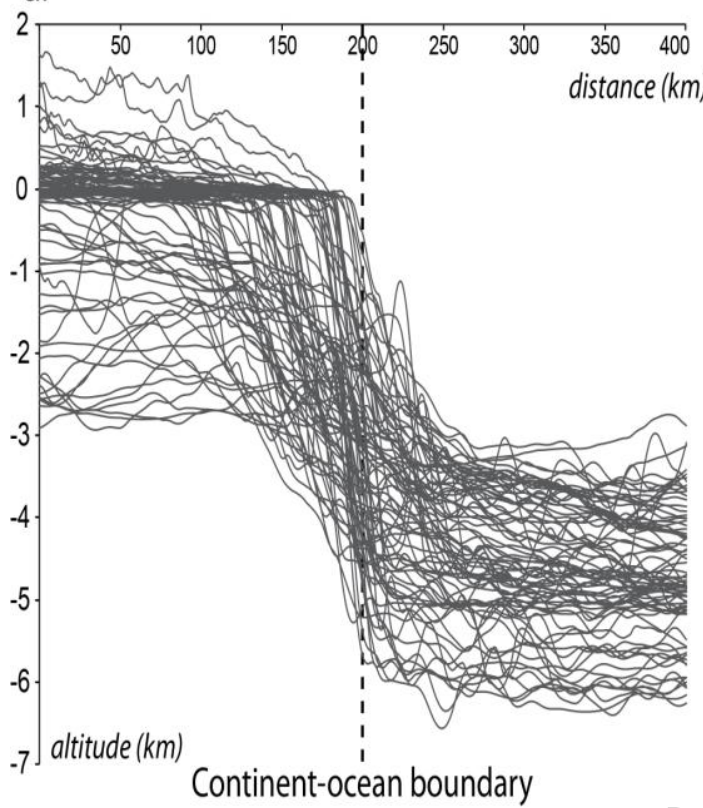

b.

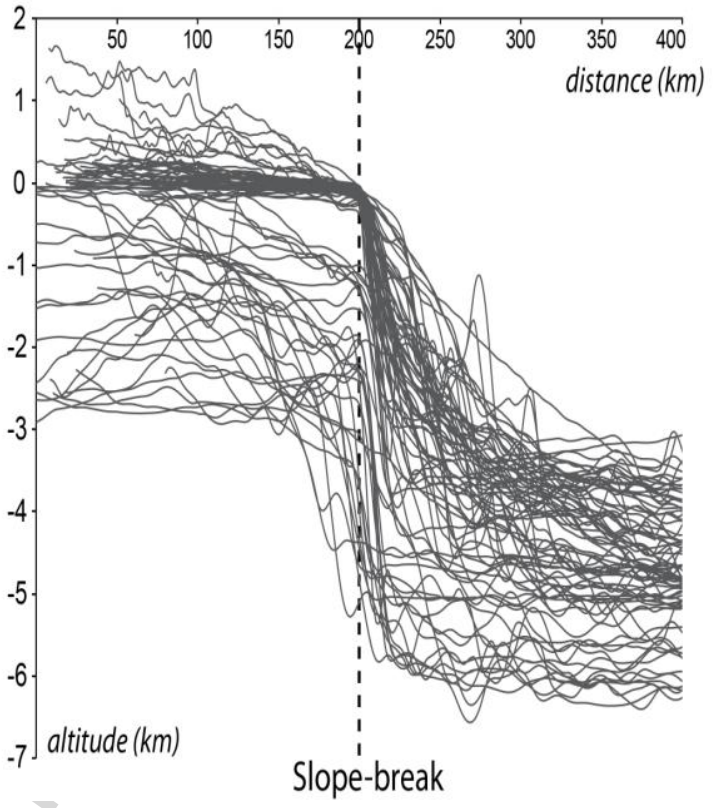

Fig. 7 

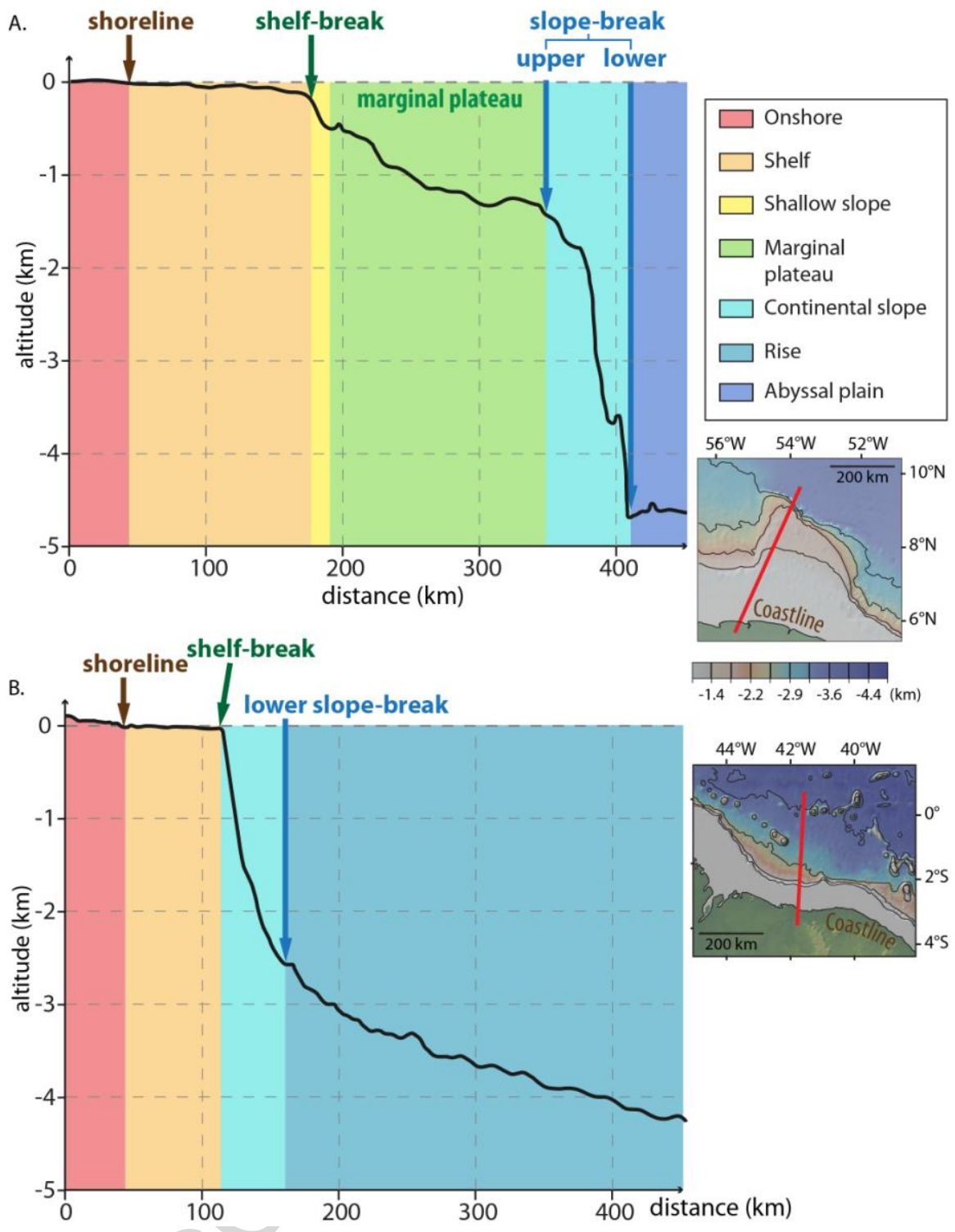

Fig. 8 

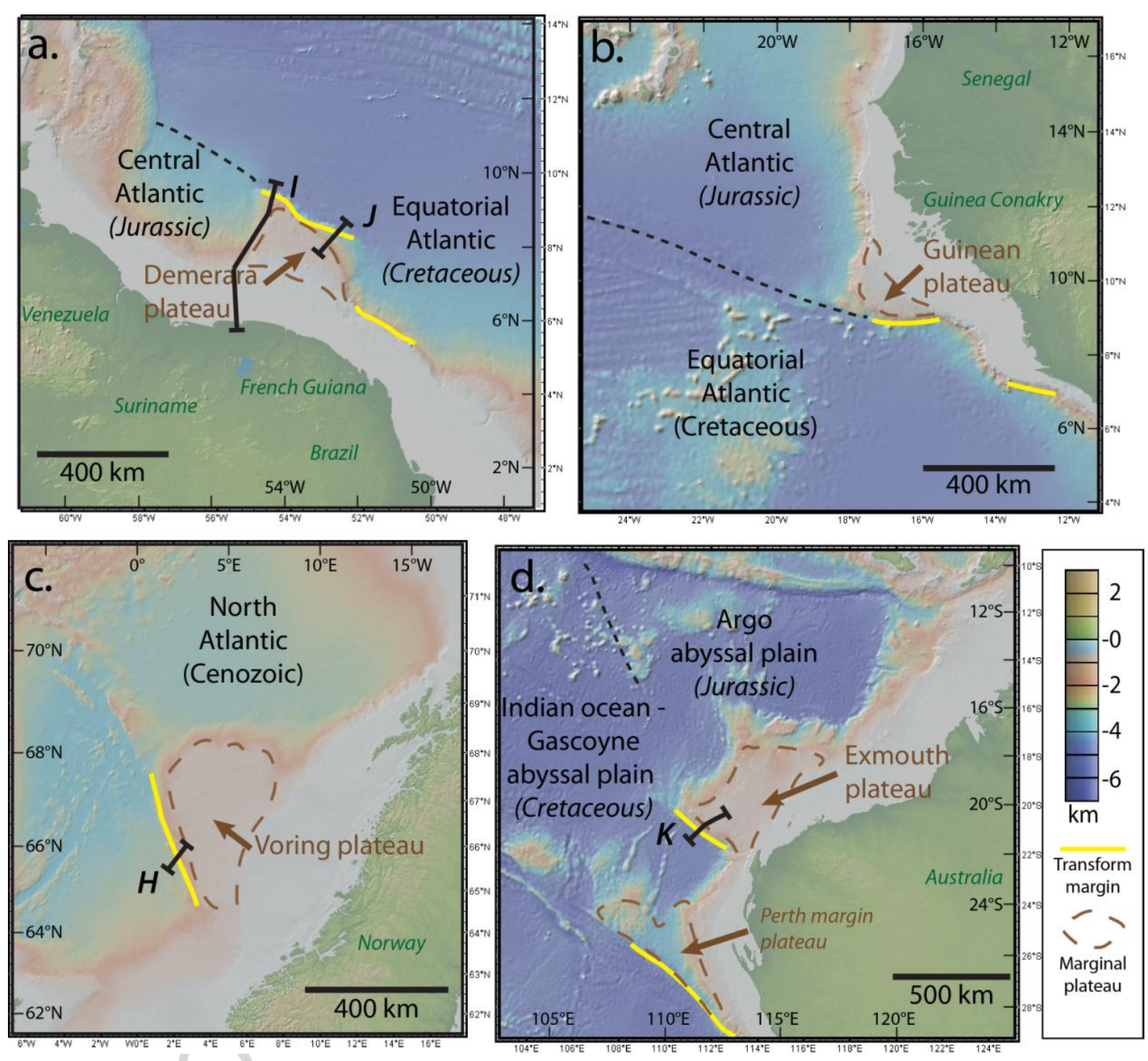

Fig. 10 
a.

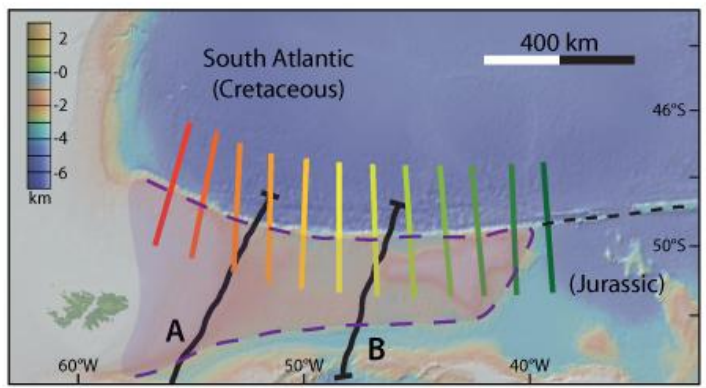

b.

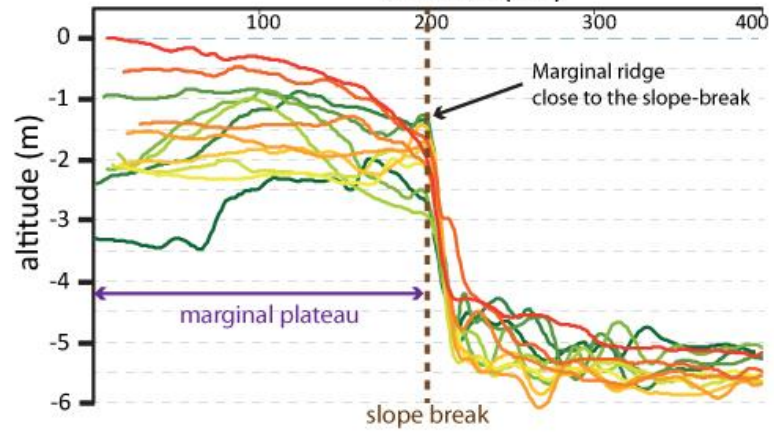

C.

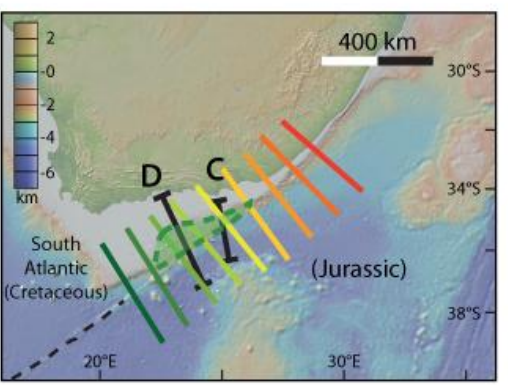

d.

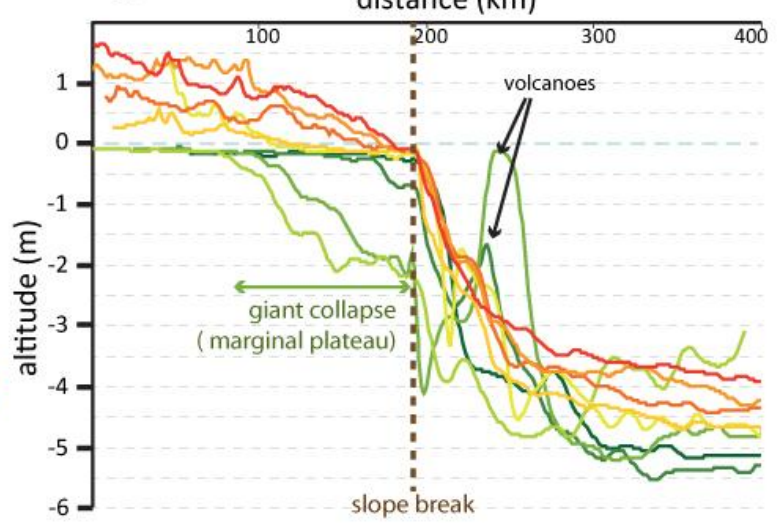

Fig. 11 
a.

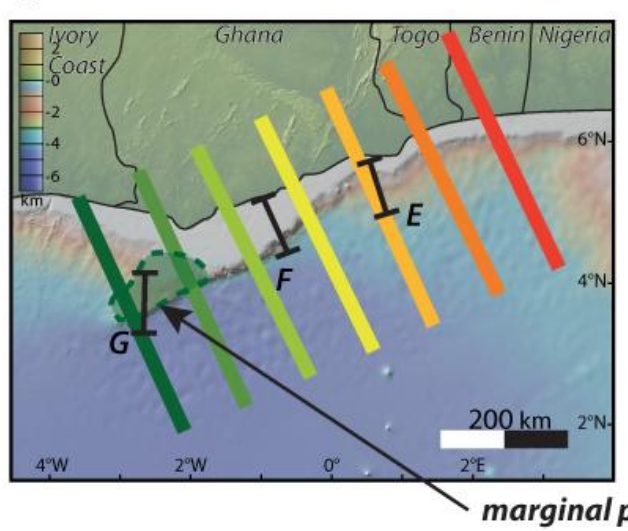

b.

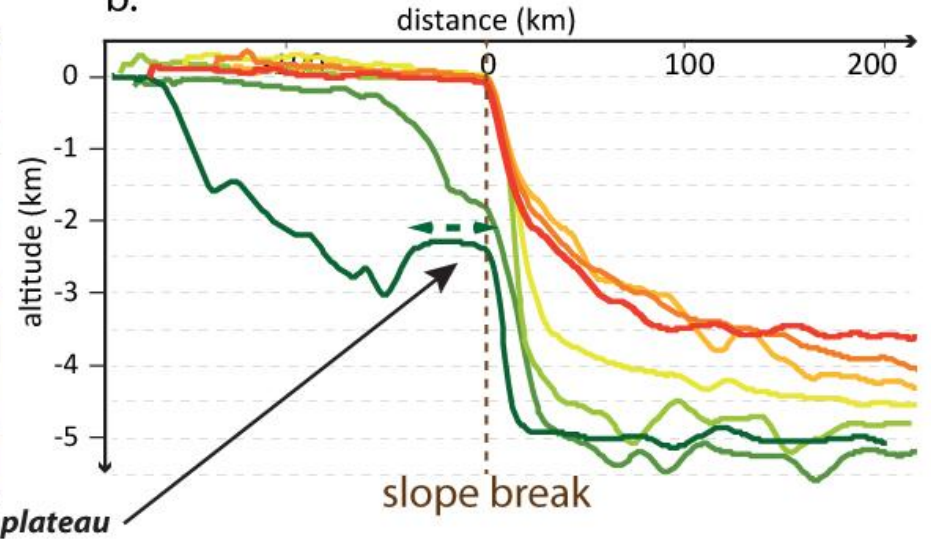

Fig. 12 

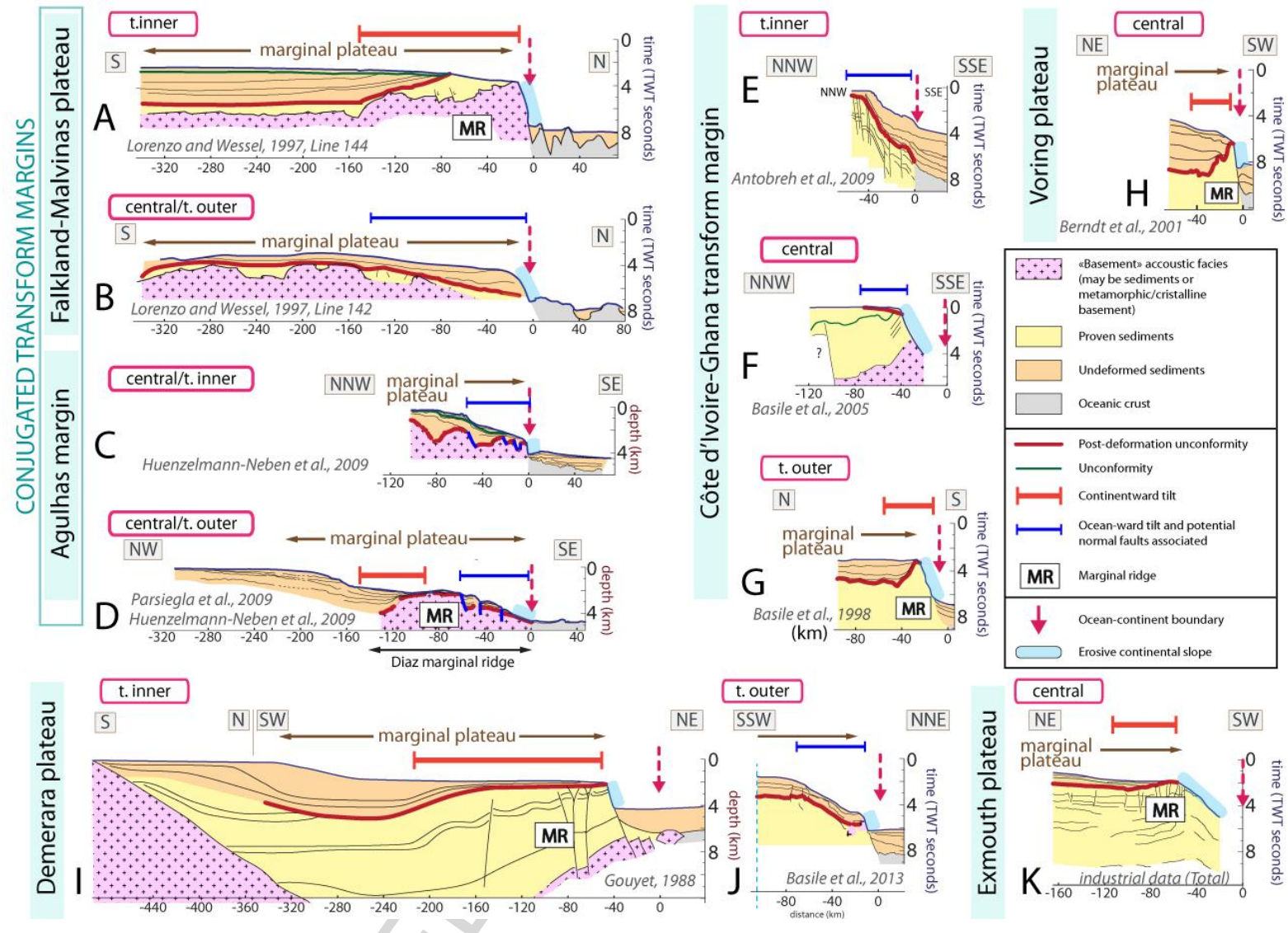

$$
\text { t. outer }
$$

NE SSW

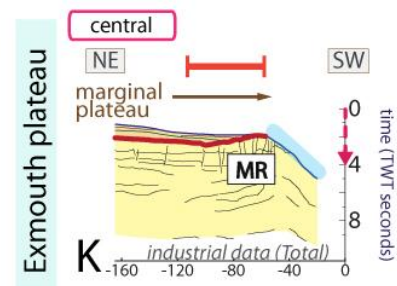

Fig. 13 
A Amazon fan divergent margin

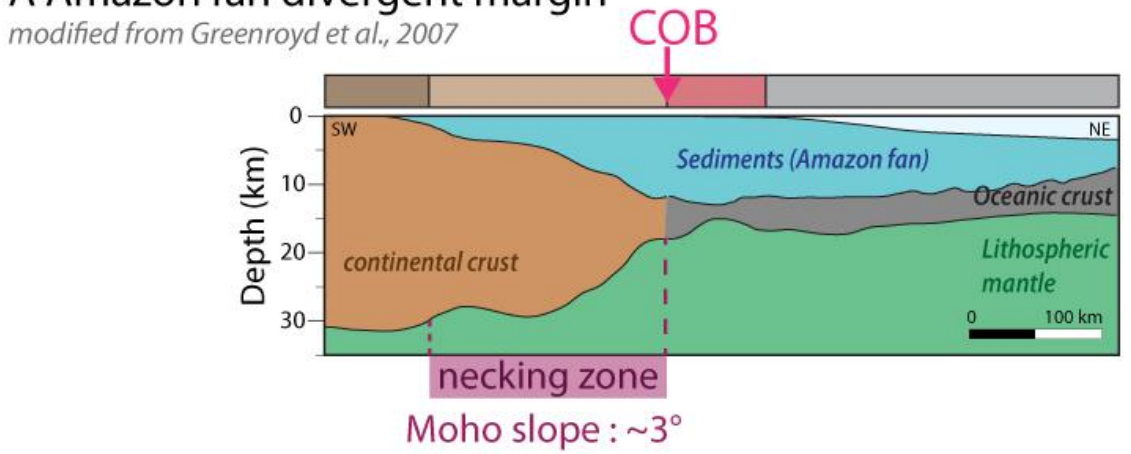

B Eastern French Guiana transform

modified from

Greenroyd et al., 2008
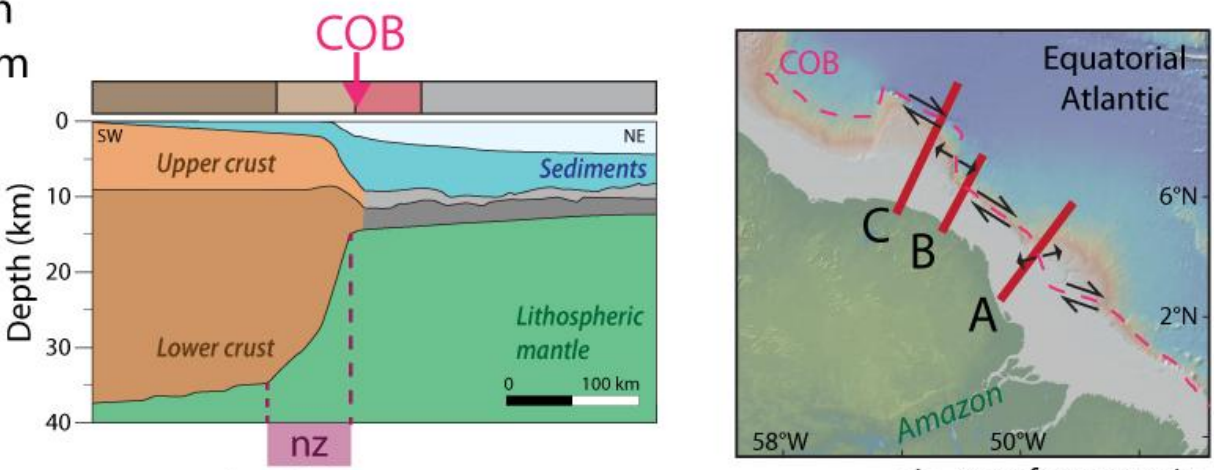

$\gtrless$ transform margin

C Northern Demerara Moho slope : $\sim 8^{\circ}$

$\leftarrow$ divergent margin

\section{transform margin}

modified from Rodger et al., 2008

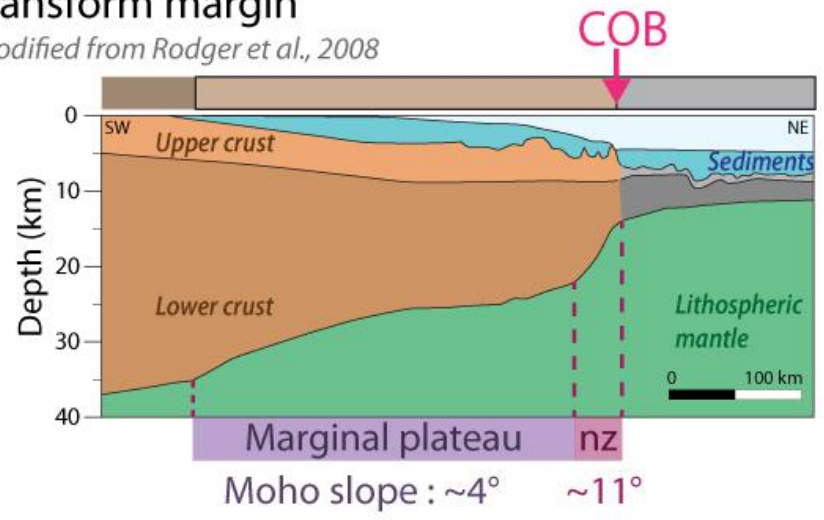

\section{Crustal domains :}

Continental crust

Thinned continental crust

Abnormal oceanic crust

Oceanic crust

$\mathrm{nz}$ Necking zone

COB Continent-ocean boundary

Fig. 14 


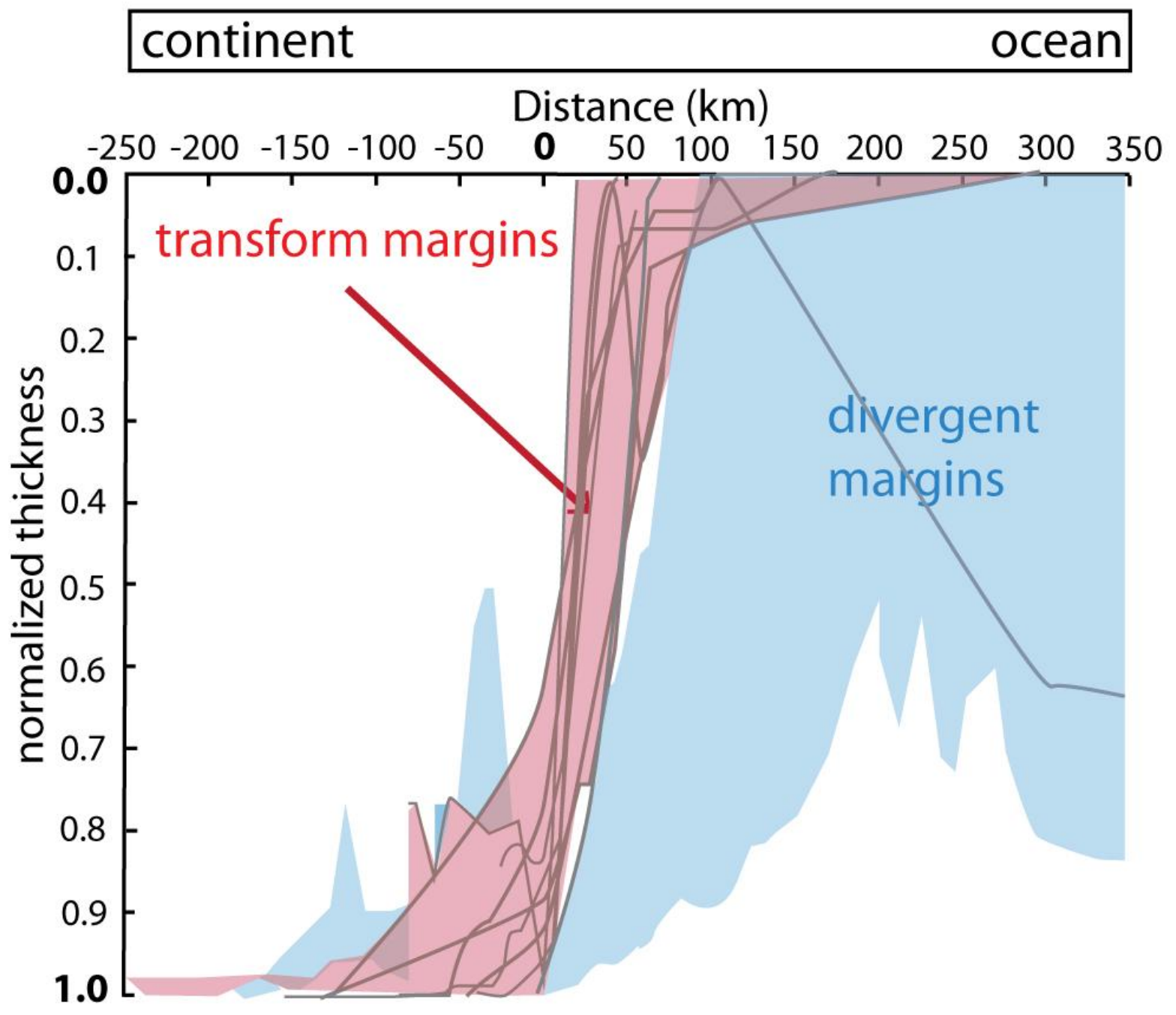

Fig. 15 


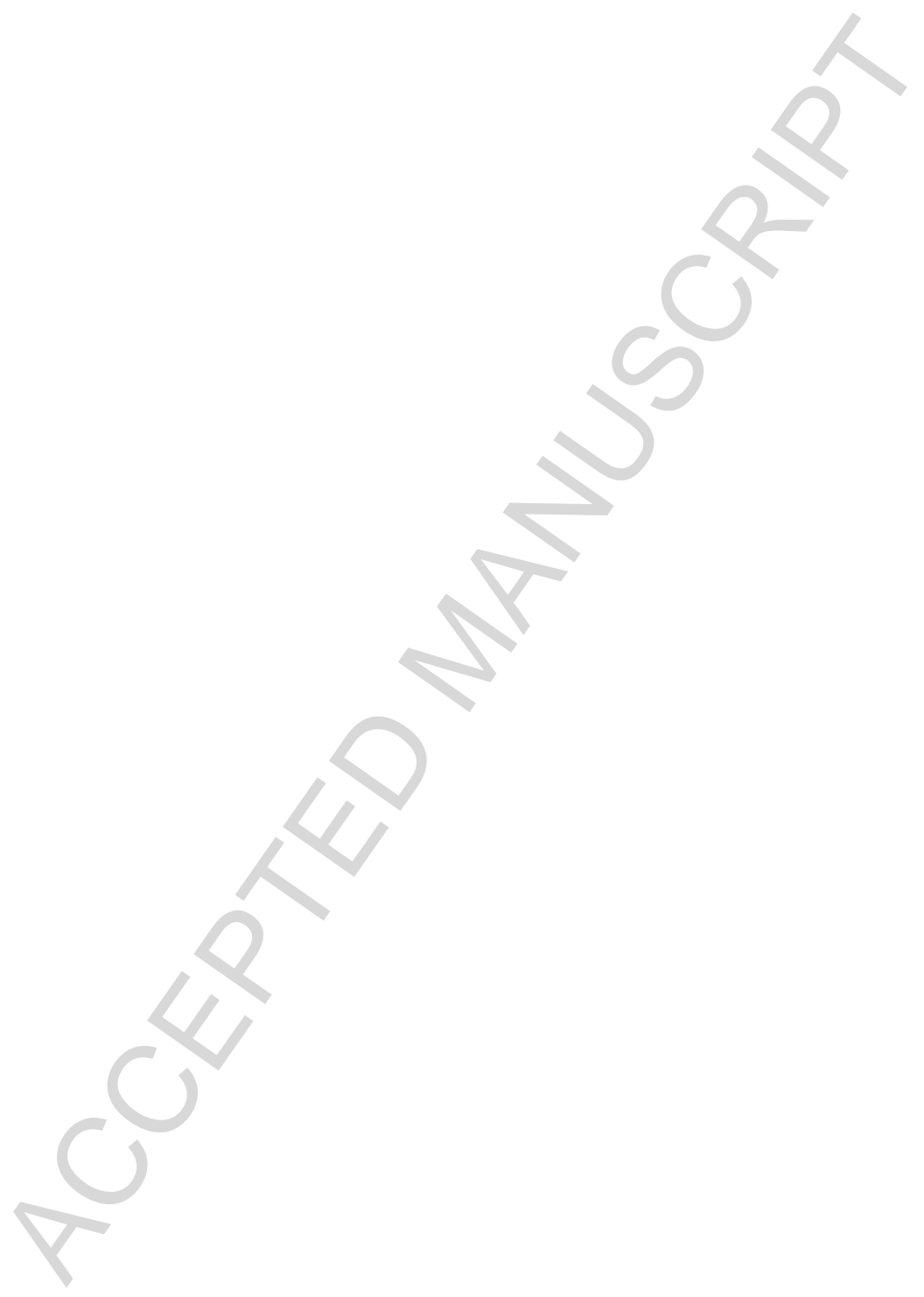


Table 1

\begin{tabular}{|c|c|c|c|c|c|c|c|c|c|c|c|c|}
\hline $\begin{array}{l}\text { Margin } \\
\text { name }\end{array}$ & $\begin{array}{l}\text { Abbreviat } \\
\text { ion }\end{array}$ & $\begin{array}{l}\text { Geographic } \\
\text { domain }\end{array}$ & $\begin{array}{l}\text { Conjugated } \\
\text { margin } \\
\text { abbreviatio } \\
\text { n }\end{array}$ & $\begin{array}{l}\text { Identificati } \\
\text { on method }\end{array}$ & Length (km) & $\begin{array}{l}\text { Age of } \\
\text { first } \\
\text { oceanic } \\
\text { accretion } \\
\text { close to } \\
\text { inner } \\
\text { corner } \\
\text { (Myrs) } \\
\end{array}$ & $\begin{array}{l}\text { Age of } \\
\text { last } \\
\text { transfor } \\
\text { m } \\
\text { activity } \\
\text { along the } \\
\text { transfor } \\
\text { m } \\
\text { margin } \\
\text { (Myrs) }\end{array}$ & $\begin{array}{l}\text { Transf } \\
\text { orm } \\
\text { stage } \\
\text { durati } \\
\text { on } \\
\text { (Myrs) }\end{array}$ & $\begin{array}{l}\text { Used } \\
\text { for } \\
\text { Bathy } \\
\text { metric } \\
\text { invent } \\
\text { ory }\end{array}$ & $\begin{array}{l}\text { Margi } \\
\text { nal } \\
\text { plate } \\
\text { au }\end{array}$ & $\begin{array}{l}\text { If } \\
\text { pres } \\
\text { ent, } \\
\text { type } \\
\text { of } \\
\text { mar } \\
\text { ginal } \\
\text { ridg } \\
\text { e(s) }\end{array}$ & $\begin{array}{l}\text { Key } \\
\text { refe } \\
\text { renc } \\
\text { es }\end{array}$ \\
\hline $\begin{array}{l}\text { NorthEast } \\
\text { Greenlan } \\
\text { d }\end{array}$ & NEG & $\begin{array}{l}\text { North } \\
\text { Atlantic }\end{array}$ & $\begin{array}{l}\text { Senja and } \\
\text { Spitz }\end{array}$ & $\begin{array}{l}\text { Müller \& } \\
\text { COB }\end{array}$ & 260 & & 9 & 47 & & & & $\begin{array}{l}\text { Doss } \\
\text { ing } \\
\text { et al., } \\
2010 \\
\end{array}$ \\
\hline Senja & Senja & $\begin{array}{l}\text { North } \\
\text { Atlantic }\end{array}$ & NEG and EGR & $\begin{array}{l}\text { Müller \& } \\
\text { COB }\end{array}$ & 370 & 48 & 29 & 19 & & & & $\begin{array}{l}\text { Jacks } \\
\text { on, } \\
1990 \\
; \\
\text { Breiv } \\
\text { ik et } \\
\text { al., } \\
2003\end{array}$ \\
\hline $\begin{array}{l}\text { Spitzberg } \\
\text { /Hornsun } \\
\text { d }\end{array}$ & Spitz & $\begin{array}{l}\text { North } \\
\text { Atlantic }\end{array}$ & NEG & $\begin{array}{l}\text { K (Breivik } \\
\text { et al., 2003) }\end{array}$ & 490 & 34 & 18 & 16 & & & & $\begin{array}{l}\text { Jacks } \\
\text { on, } \\
1990 \\
; \\
\text { Breiv } \\
\text { ik et } \\
\text { al., } \\
2003 \\
; \\
\text { Liba } \\
\text { k et } \\
\text { al., } \\
2012\end{array}$ \\
\hline $\begin{array}{l}\text { East } \\
\text { Greenlan }\end{array}$ & EGR & $\begin{array}{l}\text { North } \\
\text { Atlantic }\end{array}$ & Senja & $\mathrm{K}$ & 110 & & & & & yes & & $\begin{array}{l}\text { Doss } \\
\text { ing }\end{array}$ \\
\hline
\end{tabular}

70 


\begin{tabular}{|c|c|c|c|c|c|c|c|c|c|c|}
\hline d Ridge & & & & & & & & & & $\begin{array}{l}\text { et al., } \\
2008\end{array}$ \\
\hline & & & & $\begin{array}{l}\text { (Dossing et } \\
\text { al., 2012) }\end{array}$ & & & & & & \\
\hline $\begin{array}{l}\text { Jan } \\
\text { Mayen }\end{array}$ & JM & $\begin{array}{l}\text { North } \\
\text { Atlantic }\end{array}$ & Vor & FZ \& COB & 150 & & & & yes & $\begin{array}{l}\text { Gern } \\
\text { igon } \\
\text { et al., } \\
2009\end{array}$ \\
\hline Vøring & Vor & $\begin{array}{l}\text { North } \\
\text { Atlantic }\end{array}$ & JM & FZ \& COB M & 180 & C & 49 & 5 & yes & $\begin{array}{l}\text { Bern } \\
\text { dt et } \\
\text { al., } \\
2001\end{array}$ \\
\hline $\begin{array}{l}\text { Ungava } \\
\text { Canada }\end{array}$ & UnC & Labrador & UnG & $\begin{array}{l}\text { K (Reid and } \\
\text { Jackson, } \\
\text { 1997) }\end{array}$ & 400 & 55 & 42 & 13 & & $\begin{array}{l}\text { Reid } \\
\text { and } \\
\text { Jacks } \\
\text { on, } \\
1997 \\
; \\
\text { Func } \\
\text { k et } \\
\text { al., } \\
2007\end{array}$ \\
\hline $\begin{array}{l}\text { Ungava } \\
\text { Greenlan } \\
\text { d }\end{array}$ & UnG & Labrador & UnC & $\begin{array}{l}\text { K (Reid and } \\
\text { Jackson, } \\
\text { 1997) }\end{array}$ & 290 & 63 & 39 & 24 & & $\begin{array}{l}\text { Reid } \\
\text { and } \\
\text { Jacks } \\
\text { on, } \\
1997 \\
; \\
\text { Func } \\
\text { k et } \\
\text { al., } \\
2007 \\
\end{array}$ \\
\hline Baffin 1 & Baff1 & Labrador & Baff2 & $\begin{array}{l}\text { Müller \& } \\
\text { COB }\end{array}$ & 140 & & & & & \\
\hline Baffin 2 & Baff2 & Labrador & Baff1 & $\begin{array}{l}\text { Müller \& } \\
\text { COB }\end{array}$ & 120 & & & & & \\
\hline $\begin{array}{l}\text { North } \\
\text { Baffin }\end{array}$ & NBaff & Labrador & $?$ & $\begin{array}{l}\text { K (Reid and } \\
\text { Jackson, } \\
\text { 1997) }\end{array}$ & 300 & 76 & 61 & 5 & & $\begin{array}{l}\text { Reid } \\
\text { and } \\
\text { Jacks } \\
\text { on, }\end{array}$ \\
\hline
\end{tabular}




\begin{tabular}{|c|c|c|c|c|c|c|c|c|c|c|c|c|}
\hline & & & & & & & & & & & & 1997 \\
\hline $\begin{array}{l}\text { Cartwrigh } \\
\mathrm{t}\end{array}$ & Cart & $\begin{array}{l}\text { North } \\
\text { Atlantic }\end{array}$ & SG & $\begin{array}{l}\text { K (Reid and } \\
\text { Jackson, } \\
\text { 1997) }\end{array}$ & 140 & & & & & & & $\begin{array}{l}\text { Oake } \\
\text { y } \\
2012\end{array}$ \\
\hline $\begin{array}{l}\text { South } \\
\text { Greenlan } \\
\text { d }\end{array}$ & SG & $\begin{array}{l}\text { North } \\
\text { Atlantic }\end{array}$ & Cart & $\mathrm{K}$ & 110 & & & & & & & \\
\hline $\begin{array}{l}\text { Orphan } \\
\text { basin } \\
\text { transform } \\
\text { margin }\end{array}$ & Orph & $\begin{array}{l}\text { SouthernNo } \\
\text { rth Atlantic }\end{array}$ & $\mathrm{RP}$ & FZ \& COB & 210 & 83 & 64 & 19 & & & & \\
\hline $\begin{array}{l}\text { RockallTr } \\
\text { ough }\end{array}$ & RP & $\begin{array}{l}\text { SouthernNo } \\
\text { rth Atlantic }\end{array}$ & Orph & FZ \& COB & 260 & 81 & 59 & 22 & & yes & & $\begin{array}{l}\text { Bull } \\
\text { et al., } \\
1996\end{array}$ \\
\hline $\begin{array}{l}\text { Newfoun } \\
\text { dland } \\
\text { plateau }\end{array}$ & Newf & $\begin{array}{l}\text { SouthernNo } \\
\text { rth Atlantic }\end{array}$ & $\begin{array}{l}\text { Re- } \\
\text { activatedmar } \\
\text { gin }\end{array}$ & FZ \& COB & 480 & 171 & 126 & 45 & Yes & yes & $\begin{array}{l}\text { Flex } \\
\text { ural }\end{array}$ & $\begin{array}{l}\text { Reid, } \\
1988\end{array}$ \\
\hline $\begin{array}{l}\text { East US } \\
\text { Coast (2 } \\
\text { transfor } \\
\text { m } \\
\text { margins) }\end{array}$ & EUSC & $\begin{array}{l}\text { Central } \\
\text { Atlantic }\end{array}$ & $\begin{array}{l}\text { Not } \\
\text { identified }\end{array}$ & FZ \& COB & $\sim 70$ & & & & Yes & & & \\
\hline $\begin{array}{l}\text { Blake } \\
\text { Spur }\end{array}$ & BS & $\begin{array}{l}\text { Central } \\
\text { Atlantic }\end{array}$ & $\begin{array}{l}\text { Not } \\
\text { identified }\end{array}$ & FZ \& COB & 200 & 179 & 173 & 6 & Yes & yes & & \\
\hline $\begin{array}{l}\text { JacksonVi } \\
\text { lle }\end{array}$ & $\mathrm{Jv}$ & $\begin{array}{l}\text { Central } \\
\text { Atlantic }\end{array}$ & $\begin{array}{l}\text { Not } \\
\text { identified }\end{array}$ & FZ \& COB & 45 & 175 & 173 & 2 & Yes & yes & & \\
\hline Bahamas & Baham & $\begin{array}{l}\text { Central } \\
\text { Atlantic }\end{array}$ & $?$ & $\mathrm{~K}$ & 835 & & & & & & & \\
\hline $\begin{array}{l}\text { Demerara } \\
\text { Plateau }\end{array}$ & Dem & $\begin{array}{l}\text { Equatorial } \\
\text { Atlantic }\end{array}$ & Gui & $\begin{array}{l}\text { K (Campan, } \\
\text { 1995; } \\
\text { Moulin et } \\
\text { al., 2010) }\end{array}$ & 340 & 94 & 91 & 3 & Yes & yes & $\begin{array}{l}\text { Flex } \\
\text { ural - } \\
\text { (Gou } \\
\text { yet, } \\
1988 \\
\text { ) }\end{array}$ & $\begin{array}{l}\text { Gouy } \\
\text { et, } \\
1988 \\
\text {; } \\
\text { Gree } \\
\text { nroy } \\
\text { d et } \\
\text { al., } \\
2008 \\
\text {; } \\
\text { Basil } \\
\text { e et }\end{array}$ \\
\hline
\end{tabular}




\begin{tabular}{|c|c|c|c|c|c|c|c|c|c|c|c|c|}
\hline & & & & & & & & & & & & $\begin{array}{l}\text { al., } \\
2013 \\
; \\
\text { Lonc } \\
\text { ke et } \\
\text { al., } \\
\text { acce } \\
\text { pted }\end{array}$ \\
\hline $\begin{array}{l}\text { Guinea } \\
\text { Plateau }\end{array}$ & Gui & $\begin{array}{l}\text { Equatorial } \\
\text { Atlantic }\end{array}$ & Dem & $\begin{array}{l}\text { K (Campan, } \\
\text { 1995; } \\
\text { Moulin et } \\
\text { al., 2010) }\end{array}$ & 350 & 109 & 102 & 7 & Yes & yes & $\begin{array}{l}\text { Flex } \\
\text { ural } \\
\text { (Ben } \\
\text { kheli } \\
\text { l et } \\
\text { al., } \\
1989 \\
\text { ) }\end{array}$ & $\begin{array}{l}\text { Benk } \\
\text { helil } \\
\text { et al., } \\
1995\end{array}$ \\
\hline $\begin{array}{l}\text { Sierra } \\
\text { Leone } \\
\text { Plateau }\end{array}$ & SL & $\begin{array}{l}\text { Equatorial } \\
\text { Atlantic }\end{array}$ & EGF & $\begin{array}{l}\text { K (Campan, } \\
1995 ; \\
\text { Moulin et } \\
\text { al., 2010) }\end{array}$ & 200 & & & & & yes & $\begin{array}{l}\text { No } \\
\text { marg } \\
\text { inal } \\
\text { ridge }\end{array}$ & \\
\hline $\begin{array}{l}\text { Eastern } \\
\text { French } \\
\text { Guiana }\end{array}$ & EGF & $\begin{array}{l}\text { Equatorial } \\
\text { Atlantic }\end{array}$ & SL & $\begin{array}{l}\text { K (Campan, } \\
\text { 1995; } \\
\text { Moulin et } \\
\text { al., 2010) }\end{array}$ & & 108 & 101 & 7 & Yes & & $\begin{array}{l}\text { No } \\
\text { marg } \\
\text { inal } \\
\text { ridge }\end{array}$ & $\begin{array}{l}\text { Gouy } \\
\text { et, } \\
1988 \\
; \\
\text { Gree } \\
\text { nroy } \\
\text { d et } \\
\text { al., } \\
2008\end{array}$ \\
\hline $\begin{array}{l}\text { Western } \\
\text { Côte } \\
\text { d'Ivoire }\end{array}$ & Iv.C & $\begin{array}{l}\text { Equatorial } \\
\text { Atlantic }\end{array}$ & $\mathrm{Am}$ & FZ \& COB & 620 & 107 & 88 & 19 & Yes & & $\begin{array}{l}\text { No } \\
\text { marg } \\
\text { inal } \\
\text { ridge } \\
\text { (de } \\
\text { Capr } \\
\text { ona, } \\
1992 \\
\text { ) }\end{array}$ & $\begin{array}{l}\text { De } \\
\text { Capr } \\
\text { ona, } \\
1992\end{array}$ \\
\hline $\begin{array}{l}\text { Para- } \\
\text { Maranhao }\end{array}$ & $\mathrm{Am}$ & $\begin{array}{l}\text { Equatorial } \\
\text { Atlantic }\end{array}$ & Iv.C & $\begin{array}{l}\text { K (Campan, } \\
1995 ;\end{array}$ & 320 & & & & & & & $\begin{array}{l}\text { Watt } \\
\text { s et }\end{array}$ \\
\hline
\end{tabular}




\begin{tabular}{|c|c|c|c|c|c|c|c|c|c|c|c|c|}
\hline $\begin{array}{l}\text { (Amazon } \\
\text { delta) }\end{array}$ & & & & $\begin{array}{l}\text { Moulin et } \\
\text { al., 2010) }\end{array}$ & & & & & & & & $\begin{array}{l}\text { al., } \\
2009\end{array}$ \\
\hline $\begin{array}{l}\text { Côte } \\
\text { d'Ivoire- } \\
\text { Ghana }\end{array}$ & CIG & $\begin{array}{l}\text { Equatorial } \\
\text { Atlantic }\end{array}$ & $\mathrm{Ce}$ & FZ \& COB & 700 & 104 & 80 & 24 & Yes & yes & $\begin{array}{l}\text { Flex } \\
\text { ural } \\
\text { (Basi } \\
\text { le et } \\
\text { al., } \\
1998 \\
\text { ) }\end{array}$ & $\begin{array}{l}\text { Basil } \\
\text { e et } \\
\text { al., } \\
1998 \\
; \\
\text { Sage } \\
\text { et al., } \\
2000 \\
; \\
\text { Anto } \\
\text { breh } \\
\text { et al., } \\
2009\end{array}$ \\
\hline Ceara & $\mathrm{Ce}$ & $\begin{array}{l}\text { Equatorial } \\
\text { Atlantic }\end{array}$ & CIG & FZ \& COB & 300 & 109 & 87 & 22 & Yes & & & \\
\hline Potiguar & Pot & $\begin{array}{l}\text { Equatorial } \\
\text { Atlantic }\end{array}$ & Nig & FZ \& COB & 210 & & & & & & & \\
\hline $\begin{array}{l}\text { Niger } \\
\text { delta }\end{array}$ & Nig & $\begin{array}{l}\text { Equatorial } \\
\text { Atlantic }\end{array}$ & Pot & $\begin{array}{l}\text { K (Campan, } \\
\text { 1995; } \\
\text { Moulin et } \\
\text { al., 2010) }\end{array}$ & $110 ?$ & & & & & & & $\begin{array}{l}\text { Cobb } \\
\text { old } \\
\text { et al., } \\
2009\end{array}$ \\
\hline Maceio & Mac & $\begin{array}{l}\text { South } \\
\text { Atlantic }\end{array}$ & Nig & FZ \& COB & 110 & 120 & 115 & 5 & Yes & & & \\
\hline Benguela & Beng & $\begin{array}{l}\text { South } \\
\text { Atlantic }\end{array}$ & Not identifed & $\begin{array}{l}\text { K (Moulin et } \\
\text { al., 2010) }\end{array}$ & 330 & 119 & 115 & 4 & Yes & & $\begin{array}{l}\text { No } \\
\text { marg } \\
\text { inal } \\
\text { ridge } \\
\text { (Guir } \\
\text { aud } \\
\text { et al., } \\
2010 \\
\text { ) }\end{array}$ & $\begin{array}{l}\text { Guir } \\
\text { aud } \\
\text { et al., } \\
2010\end{array}$ \\
\hline Walvis & Walvis & $\begin{array}{l}\text { South } \\
\text { Atlantic }\end{array}$ & $\begin{array}{l}\text { Not } \\
\text { identified }\end{array}$ & FZ \& COB & 120 & & & & Yes & yes & & \\
\hline $\begin{array}{l}\text { Falklands } \\
\text {-Malvinas }\end{array}$ & Falklands & $\begin{array}{l}\text { South } \\
\text { Atlantic }\end{array}$ & Agu & FZ \& COB & 1300 & 133 & 83 & 50 & Yes & yes & $\begin{array}{l}\text { Flex } \\
\text { ural } \\
\text { and } \\
\text { base }\end{array}$ & $\begin{array}{l}\text { Ben- } \\
\text { Avra } \\
\text { ham } \\
\text { et al., }\end{array}$ \\
\hline
\end{tabular}




\begin{tabular}{|c|c|c|c|c|c|c|c|c|c|c|c|c|}
\hline & & & & & & & & & & & $\begin{array}{l}\text { ment } \\
\text { high } \\
\text { (Lor } \\
\text { enzo } \\
\text { and } \\
\text { Wess } \\
\text { el, } \\
1989 \\
\text { ) }\end{array}$ & $\begin{array}{l}1993 \\
; \\
\text { Lore } \\
\text { nzo } \\
\text { and } \\
\text { Wess } \\
\text { el, } \\
1997\end{array}$ \\
\hline Agulhas & Agu & $\begin{array}{l}\text { South } \\
\text { Atlantic }\end{array}$ & Falklands & $\mathrm{FZ} \& \mathrm{COB}$ & 990 & & 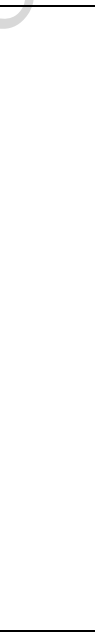 & & Yes & yes & $\begin{array}{l}\text { Base } \\
\text { ment } \\
\text { high } \\
\text { (Ben } \\
- \\
\text { Avra } \\
\text { ham, } \\
1993 \\
\text { ) }\end{array}$ & 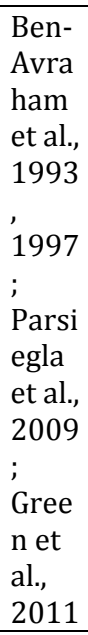 \\
\hline $\begin{array}{l}\text { Mozambi } \\
\text { que (3 } \\
\text { transfor } \\
\text { mmargin } \\
\text { s) }\end{array}$ & Moz & $\begin{array}{l}\text { Africa- } \\
\text { Antarctic }\end{array}$ & Dron? & $\begin{array}{l}\text { Müller \& } \\
\text { COB }\end{array}$ & $\sim 2350$ & $\sim 155$ & $\sim 137$ & $\sim 18$ & & & & \\
\hline $\begin{array}{l}\text { Somali } \\
\text { basin } \\
\text { margin }\end{array}$ & Som & $\begin{array}{l}\text { Africa- } \\
\text { Antarctic }\end{array}$ & Mad. SW & FZ \& COB & 1140 & 155 & 143 & 12 & & & & $\begin{array}{l}\text { Mou } \\
\text { geno } \\
\text { t et } \\
\text { al., } \\
1991 \\
\end{array}$ \\
\hline $\begin{array}{l}\text { SouthWes } \\
\mathrm{t} \\
\text { Madagasc } \\
\text { ar }\end{array}$ & Mad.SW & $\begin{array}{l}\text { Africa- } \\
\text { Antarctic }\end{array}$ & Som & FZ \& $\mathrm{COB}$ & 430 & 136 & 112 & 24 & & & & \\
\hline
\end{tabular}




\begin{tabular}{|c|c|c|c|c|c|c|c|c|c|c|c|c|}
\hline $\begin{array}{l}\text { Dronning } \\
\text { land } \\
\text { plateau }\end{array}$ & Dron & $\begin{array}{l}\text { Africa- } \\
\text { Antarctic }\end{array}$ & Moz? & FZ \& COB & 550 & & & & Yes & yes & & \\
\hline $\begin{array}{l}\text { East } \\
\text { Madagasc } \\
\text { ar }\end{array}$ & Mad.E & $\begin{array}{l}\text { Madagascar } \\
\text {-India }\end{array}$ & $\begin{array}{l}\text { Not } \\
\text { identified }\end{array}$ & FZ \& COB & 50 & & & & Yes & & & \\
\hline $\begin{array}{l}\text { EasternA } \\
\text { ntarctictr } \\
\text { ansformm } \\
\text { argin }\end{array}$ & EATM & $\begin{array}{l}\text { India- } \\
\text { Antarctic }\end{array}$ & EICM & $\mathrm{K}$ & 630 & & & & & & & \\
\hline $\begin{array}{l}\text { EasternIn } \\
\text { dia } \\
\text { continent } \\
\text { al margin }\end{array}$ & EICM & $\begin{array}{l}\text { India- } \\
\text { Antarctic }\end{array}$ & EATM & $\begin{array}{l}\mathrm{K} \text { (Chand et } \\
\text { al., 2001) }\end{array}$ & 440 & & & & Yes & & & $\begin{array}{l}\text { Chan } \\
\text { d et } \\
\text { al., } \\
2001 \\
\end{array}$ \\
\hline $\begin{array}{l}\text { Eastern } \\
\text { Bruce } \\
\text { Rise }\end{array}$ & Bruce & $\begin{array}{l}\text { Australia- } \\
\text { Antarctic }\end{array}$ & NP & $\mathrm{K}$ & 160 & & & & & yes & & \\
\hline $\begin{array}{l}\text { Southern } \\
\text { Exmouth } \\
\text { plateau }\end{array}$ & СРТМ & $\begin{array}{l}\text { Australia- } \\
\text { GreaterIndi } \\
\text { a }\end{array}$ & $\begin{array}{l}\text { Reactivated } \\
\text { in Himalaya } \\
\text { (Greater } \\
\text { India) }\end{array}$ & FZ \& COB & 280 & 134 & 128 & 6 & Yes & yes & $\begin{array}{l}\text { Struc } \\
\text { tural } \\
\text { (Lor } \\
\text { enzo } \\
\text { and } \\
\text { Vera, } \\
1992 \\
\text { ) }\end{array}$ & $\begin{array}{l}\text { Lore } \\
\text { nzo } \\
\text { et al., } \\
1991 \\
; \\
\text { Lore } \\
\text { nzo } \\
\text { and } \\
\text { Vera, } \\
1992\end{array}$ \\
\hline $\begin{array}{l}\text { Perth } \\
\text { margin }\end{array}$ & Perth & $\begin{array}{l}\text { Australia- } \\
\text { GreaterIndi } \\
\text { a }\end{array}$ & GreaterIndia & $\mathrm{FZ} \& \mathrm{COB}$ & 490 & 129 & 110 & 19 & Yes & yes & $\begin{array}{l}\text { Flex } \\
\text { ural }\end{array}$ & \\
\hline $\begin{array}{l}\text { Naturalist } \\
\text { e plateau }\end{array}$ & NP & $\begin{array}{l}\text { Australia- } \\
\text { GreaterIndi } \\
\text { a }\end{array}$ & Bruce & $\mathrm{K}$ & 270 & 127 & 120 & 7 & & yes & & 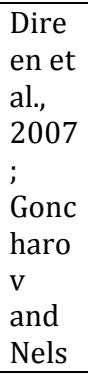 \\
\hline
\end{tabular}




\begin{tabular}{|c|c|c|c|c|c|c|c|c|c|c|c|c|}
\hline & & & & & & & & & & & & $\begin{array}{l}\text { on, } \\
2012\end{array}$ \\
\hline $\begin{array}{l}\text { Western } \\
\text { Tasmany } \\
\text { plateau }\end{array}$ & TasW & $\begin{array}{l}\text { Australia- } \\
\text { Antarctic }\end{array}$ & Ball & FZ \& COB & 630 & 41 & 22 & 19 & & yes & $\begin{array}{l}\text { Bath } \\
\text { ymet } \\
\text { ry }\end{array}$ & $\begin{array}{l}\text { Roye } \\
r \text { and } \\
\text { Rolle } \\
t, \\
1997 \\
\end{array}$ \\
\hline $\begin{array}{l}\text { Southern } \\
\text { Tasmany } \\
\text { plateau }\end{array}$ & TasS & $\begin{array}{l}\text { Australia- } \\
\text { Antarctic }\end{array}$ & Esm & FZ \& COB & 180 & 45 & 28 & 16 & & yes & $\begin{array}{l}\text { Bath } \\
\text { ymet } \\
\text { ry }\end{array}$ & $\begin{array}{l}\text { Roye } \\
r \text { and } \\
\text { Rolle } \\
t, \\
1997\end{array}$ \\
\hline $\begin{array}{l}\text { Ballenym } \\
\text { argin }\end{array}$ & Ball & $\begin{array}{l}\text { Australia- } \\
\text { Antarctic }\end{array}$ & TasW & FZ \& COB & 340 & & & & & & & $\begin{array}{l}\text { Stort } \\
\text { i et } \\
\text { al., } \\
2009\end{array}$ \\
\hline $\begin{array}{l}\text { Esmerald } \\
\text { margin }\end{array}$ & Esm & $\begin{array}{l}\text { Australia- } \\
\text { Antarctic }\end{array}$ & TasS & $\mathrm{FZ} \& \mathrm{COB}$ & 291 & 40 & 22 & 18 & & & & \\
\hline $\begin{array}{l}\text { ScotiaSeat } \\
\text { ransform } \\
\text { margin }\end{array}$ & Scot & ScotiaSea & $\begin{array}{l}\text { Not } \\
\text { identified }\end{array}$ & $\mathrm{FZ} \& \mathrm{COB}$ & 200 & & & & Yes & yes & & $\begin{array}{l}\text { Véra } \\
\text { rd et } \\
\text { al., } \\
2012\end{array}$ \\
\hline $\begin{array}{l}\text { New } \\
\text { Zealand } \\
\text { (at least } \mathbf{2} \\
\text { transfor } \\
\text { m } \\
\text { margins) }\end{array}$ & NZ & $\begin{array}{l}\text { Fidji back- } \\
\text { arc basin }\end{array}$ & & $\mathrm{K}$ & $\sim 400$ & & & & & & & \\
\hline $\begin{array}{l}\text { Woodlark } \\
(4 \\
\text { transfor } \\
\text { mmargin } \\
\text { s) }\end{array}$ & WOOD & $\begin{array}{l}\text { Woodlark } \\
\text { back-arc } \\
\text { basin }\end{array}$ & & $\begin{array}{l}\text { K (Turner et } \\
\text { al., 2009) }\end{array}$ & $\sim 60$ & & & & & & & $\begin{array}{l}\text { Tayl } \\
\text { or et } \\
\text { al., } \\
2009\end{array}$ \\
\hline $\begin{array}{l}\text { Mexico } \\
\text { Gulf (at } \\
\text { least } \mathbf{2} \\
\text { transfor } \\
\text { m } \\
\text { margins) }\end{array}$ & GOM & Mexico Gulf & & $\begin{array}{l}\text { K (Pindell } \\
\text { and Kenan, } \\
\text { 2009) }\end{array}$ & $\sim 290$ & & & & & & & \\
\hline Oriente & CT & Cayman & & $\mathrm{K}$ & 890 & & & & & & & Ten \\
\hline
\end{tabular}

77 


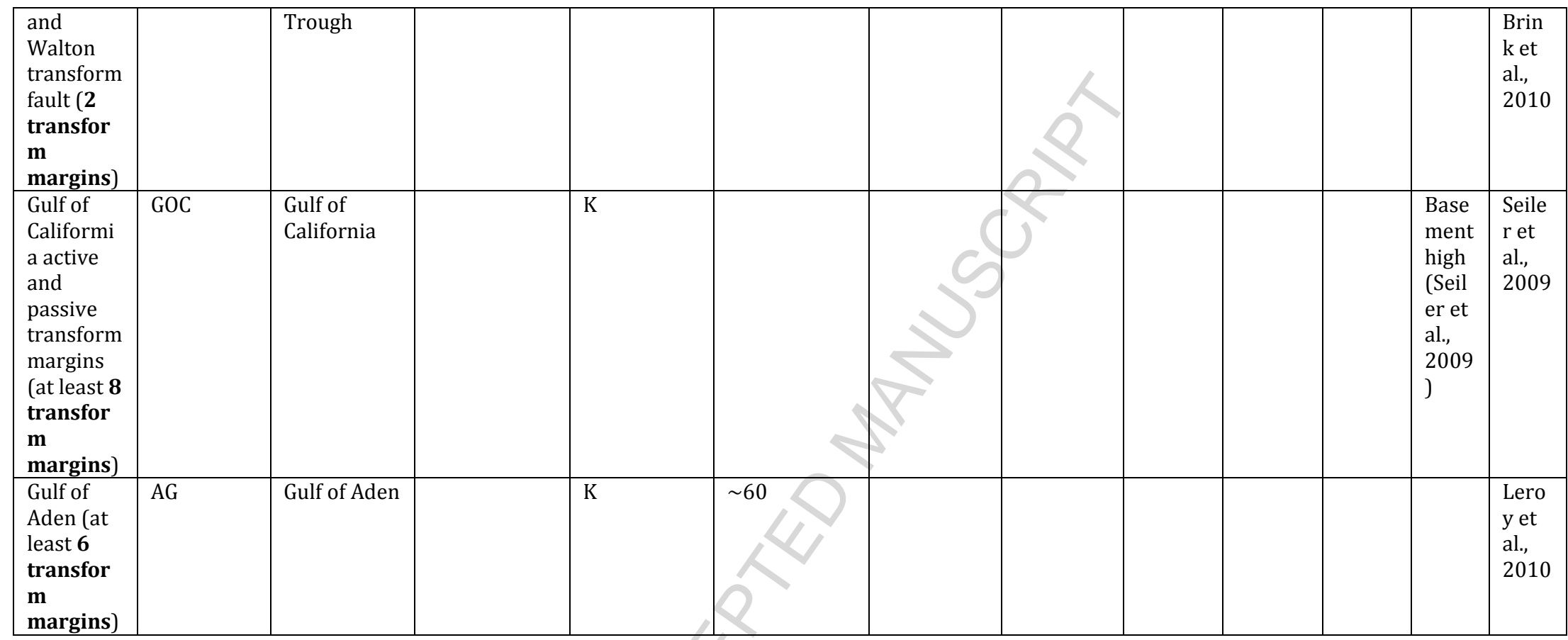


Table 2

\begin{tabular}{|l|c|c|c|c|}
\hline & Continental platform & marginal plateau & continental slope & rise and abyssal plain \\
\hline minimum slope $\left(^{\circ}\right)$ & 0 & 0 & 1.1 & 0 \\
\hline average slope $\left(^{\circ}\right)$ & 0.1 & 0.3 & 4.2 & 0 \\
\hline median slope $\left(^{\circ}\right)$ & 0.1 & 0.2 & 4.9 & 0.1 \\
\hline maximum slope $\left(^{\circ}\right)$ & 0.1 & 2 & 14 & 0.3 \\
\hline maximum width $(\mathrm{km})$ & 110 & 124 & 165 & \\
\hline minimum width $(\mathrm{km})$ & 3.5 & 9 & 16 & \\
\hline
\end{tabular}


Table 3

\begin{tabular}{|l|c|}
\hline Marginal plateau & $\begin{array}{c}\text { Duration between } \\
\text { two oceanic openings }\end{array}$ \\
\hline Brazil offshore (Maceio) & 10 \\
\hline Walvis & 15 \\
\hline Rockall Tough & 20 \\
\hline Exmouth plateau & 20 \\
\hline Morris Jesup Rise & 30 \\
\hline NortheEastGreenland & 30 \\
\hline Outeniqua & 30 \\
\hline Gunnerus Ridge & 30 \\
\hline Bruce Rise & 35 \\
\hline Tasman plateau & 40 \\
\hline Naturaliste plateau & 40 \\
\hline Newfoundland plateau & 50 \\
\hline Demerara plateau & 65 \\
\hline Guinea plateau & 65 \\
\hline
\end{tabular}

